\author{
Marquette University \\ e-Publications@Marquette
}

7-2016

\title{
Metropolitan Area Home Prices and the Mortgage Interest Deduction: Estimates and Simulations from Policy Change
}

Hal Martin

Federal Reserve Bank of Cleveland

Andrew Hanson

Marquette University, andrew.r.hanson@marquette.edu

Follow this and additional works at: https://epublications.marquette.edu/econ_fac

Part of the Economics Commons

\section{Recommended Citation}

Martin, Hal and Hanson, Andrew, "Metropolitan Area Home Prices and the Mortgage Interest Deduction: Estimates and Simulations from Policy Change" (2016). Economics Faculty Research and Publications. 575.

https://epublications.marquette.edu/econ_fac/575 
Marquette University

e-Publications@Marquette

\title{
Economics Faculty Research and Publications/College of Business Administration
}

This paper is NOT THE PUBLISHED VERSION; but the author's final, peer-reviewed manuscript. The published version may be accessed by following the link in the citation below.

Regional Science and Urban Economics, Vol. 59 (2016): 12-23. DOI. This article is (C) Elsevier and permission has been granted for this version to appear in e-Publications@Marquette. Elsevier does not grant permission for this article to be further copied/distributed or hosted elsewhere without the express permission from Elsevier.

\section{Metropolitan area home prices and the mortgage interest deduction: Estimates and simulations from policy change}

Hal Martin

Federal Reserve Bank of Cleveland, PO Box 6387, Cleveland, $\mathrm{OH}$

Andrew Hanson

Marquette University, PO Box 1881, Milwaukee, WI

\begin{abstract}
We simulate changes to metropolitan area home prices from reforming the Mortgage Interest Deduction (MID). Price simulations are based on an extended user cost model that incorporates two dimensions of behavioral change in home buyers: sensitivity of borrowing and the propensity to use tax deductions. We simulate prices with both inelastic and elastic supply. Our results show a wide range of price effects across metropolitan areas and prospective policies. Considering behavioral change and no supply elasticity, eliminating the MID results in average home price declines as steep as
\end{abstract}


$13.5 \%$ in Washington, D.C., and as small as 3.5\% in Miami-Fort Lauderdale, FL. Converting the MID to a $15 \%$ refundable credit reduces prices by as much as $1.4 \%$ in San Jose, CA, San Francisco, CA, and Washington, D.C. and increases average price in other metropolitan areas by as much as $12.1 \%$ (MiamiFort Lauderdale). Accounting for market elasticities produces price estimates that are on average $36 \%$ as large as standard estimates.

\section{Keywords}

House prices, Housing subsidy, Mortgage interest deduction

\section{Introduction}

Outstanding mortgage debt on one to four family residences peaked at over $\$ 11$ trillion in 2008 , and is currently $\$ 9.8$ trillion (Federal Reserve Board of Governors, 2015). Depending on the year, taxpayers use between three and five percent of this debt in the form of the mortgage interest tax deduction (MID), to reduce their annual tax liability. The MID is effectively the largest housing-related subsidy in the United States with a price tag of over $\$ 100$ billion/year during the housing market peak (currently $\$ 70$ billion). Despite its seemingly small size relative to the mortgage market, the MID has a substantial distortionary impact on financing (Dunsky and Follain, 2000, Dunsky and Follain, 1997, Hendershott and Pryce, 2006, Poterba and Sinai, 2011), the size of dwelling choice (Hanson, 2012a), and the transition from renter to owner (Green and Vandell, 1999). Theoretical models and simulation also link the MID to suburbanization and sorting within cities (Voith and Gyourko, 2002) and to locational choice across metropolitan areas (Albouy and Hanson, 2014).

Less remarked on than behavioral distortions, but important for how the MID affects urban areas, is how it relates to home prices. Hilber and Turner (2014) offer empirical estimates suggesting that the current MID policy is capitalized into house prices more in highly regulated markets, with regulation being a determinant of supply elasticity. Of primary concern is how changing the MID might impact home prices. Home equity is a significant component of homeowner wealth, so significant changes to home prices would impact a household's current and future spending ability. Significant home price changes from any MID reform may also impact locational choice within and across metropolitan areas. Academic work on the price effects of reforming the MID is thin, estimates vary considerably, and most are based on pre-2008 housing market data. ${ }^{1}$

We produce up-to-date estimates of the home price effects for several MID policy alternatives with a modern user cost of housing model that includes behavioral change parameters. Our simulations cover home price effects in 34 metro areas for three different policy reforms: eliminating the MID, capping the MID, and converting it to a tax credit. Methodologically, we improve on the familiar user cost of housing model by adding parameters that capture behavioral change when MID policy changes. Our behavioral change parameters are estimated using data across housing markets on the sensitivity of tax itemization rates and loan to value (LTV) ratios to the intensity of the MID. We estimate these relationships using state-level variation in MID policy with standard ordinary least squares (OLS) and instrumental variables (IV) regressions, using data from the Internal Revenue Service (IRS) and the American Housing Survey (AHS).

We add to the existing literature by incorporating local housing supply elasticities in our price simulations, and by comparing these with simulations that assume perfectly inelastic supply across markets. In each case our findings show that simulated price changes vary substantially across metropolitan areas, policy changes, and when we consider behavioral change. In inelastic supply 
models with behavioral change, eliminating the MID results in an average home price decline in Washington, D.C. of $13.5 \%$, but only a 3.5\% decline in Miami-Fort Lauderdale, FL. Converting the MID to a $15 \%$ refundable credit reduces prices by as much as $1.4 \%$ in San Jose, CA and increases average price in other metropolitan areas by as much as $12.1 \%$ (Miami-Fort Lauderdale). Estimates considering behavioral change in the itemization rate and LTV ratio result in price change estimates that differ by as much as 2.4 percentage points from the standard model. In models that incorporate elasticities from the empirical literature, price changes are substantially muted: for instance, considering local supply elasticity shrinks the price decline from eliminating the MID in Washington, D.C. from 13.5 to just $4.2 \%$. On average simulations that use empirical elasticities to characterize local markets show price changes that are only $36 \%$ as large as the models that assume perfectly inelastic supply.

The paper proceeds as follows: Section 2 summarizes the user cost model that forms the basis for evaluating house price changes; Section 3 briefly describes the data used to calibrate the user cost model parameters and demonstrates the empirical estimation strategy for behavioral change parameters; Section 4 describes adjustments to the model to simulate tax policy and presents the results; Section 5 concludes.

\section{Home prices and the user cost model}

We model home prices and subsequent changes with a user cost model. This model treats housing as a capital asset and, properly specified, describes the opportunity cost of holding the asset in a given period. ${ }^{2}$ The model implies that in a competitive equilibrium a homeowner's marginal cost of housing services is equal to the opportunity cost of homeownership, which is termed his imputed rent. For a simple, durable asset with no tax preference and a stable value, the imputed rent is straightforward: the opportunity cost of obtaining the good is the interest one would have earned with the money used to purchase the asset (or if the asset is debt financed, it is the explicit outlay of interest payments for the loan). Assuming the interest rate is the same in either case, one can write

$$
R=\operatorname{Pr}
$$

where $R$ is the imputed rent over a given period, $P$ the purchase price and $r$ the period interest rate. By rearranging terms, we can characterize the user cost of a unit of housing services, or UC:

$$
U C=\frac{R}{P}=r .
$$

Housing is, of course, neither entirely durable nor stable in value over time. The asset deteriorates, homeowners make repairs, and market conditions alter the expected future return from selling the asset. Also, local communities typically charge property tax. Adding these features to the model yields a user cost of:

$$
U C=r+\tau_{p}+m+\delta-\pi
$$

where $m$ and $\delta$ reflect annual maintenance and depreciation costs respectively, $\pi$ reflects the expected price appreciation rate, and $\tau_{p}$ is the local property tax rate.

The tax treatment of housing must also include the MID and property tax deductions. ${ }^{3}$ For every dollar of mortgage interest (or property tax) paid, the homeowner reduces his taxable income by one dollar, and his tax burden falls by one dollar times his marginal tax rate (MTR), $\tau_{\text {inc }}$. This rate of tax savings is called the marginal subsidy rate (MSR) of the MID. Considering this tax treatment, the user cost becomes: 


$$
U C=\left(1-\tau_{i n c}\right)\left(r+\tau_{p}\right)+m+\delta-\pi .
$$

This is the characterization of user cost presented in Poterba (1992).

Poterba and Sinai (2011) provide further revisions to the user cost model. They include: the flexibility for a homeowner to split financing between debt and equity; a distinct risk class for returns to homeownership; the benefit to homeowners from the option to prepay or default on their mortgage; and the flexibility for homeowners to characterize property taxes as either a benefit or an excise tax. The full model incorporating these features is given in Eq. (1) of Poterba and Sinai (2011), ${ }^{4}$ and in our notation is:

(5) $U C=\left[1-\left\{\tau_{\text {inc }} * \lambda+\tau_{y} *(1-\lambda)\right\}\right] * r_{T}+\left(1-\tau_{y}\right) * \beta-\tau_{\text {inc }} * \lambda *\left(r_{M}-r_{T}\right)+m+\delta+$ $\left(1-\tau_{\text {inc }}-\kappa\right) * \tau_{p}-\pi$

where $\lambda$ is the percent of the home value financed through debt (i.e. the LTV ratio), $\tau_{y}$ is the income tax rate on capital gains, $r_{T}$ is the risk-free rate of return in the market, $r_{M}$ is the mortgage interest rate, $b$ is the risk premium associated with homeownership and $k$ signifies the degree to which homeowners perceive the property tax to be a benefit tax (versus an excise tax). ${ }^{5}$

In order to operationalize the model to simulate a city's housing market using aggregated data, we modify it as follows:

$$
U C_{k}=I(g)_{k} * U C_{\text {Itemize }, k}+\left(1-I(g)_{k}\right) * U C_{\text {Standard }, k .}
$$

This is the weighted average user cost across market $k$ of households that itemize deductions (and face $U C_{\text {Itemize }}$ ) and those that take the standard deduction (and face $\left.U C_{\text {standard }}\right) . I(g)_{k}$ is the portion of tax filers who itemize their deductions in market $k$. It depends on the marginal subsidy rate $g$; empirically, as the MSR increases, more tax filers are inclined to itemize their returns.

We make several other changes to the user cost model in order to make it sufficiently flexible to simulate the price effects of changing tax policy. First, we posit that LTV ratios are sensitive to the deductibility of mortgage interest. ${ }^{6}$ The model expresses $\lambda(g)_{k}$, the LTV ratio, as a function of the MSR in market $k$. We also separate the marginal tax rate that applies to deductibility, $\tau_{i n c}$, into deductibility

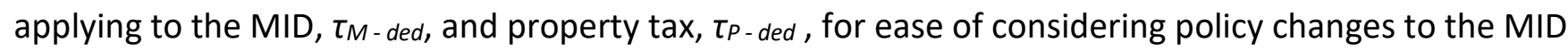
without changing property tax deductibility. With these changes, the user cost facing itemizers becomes:

(7) $U C_{\text {Itemize, },}=\left[1-\left\{\tau_{M-\text { ded }, k} * \lambda(g)_{k}+\tau_{y} *\left(1-\lambda(g)_{k}\right)\right\}\right] * r_{T}+\left(1-\tau_{y}\right) * \beta-\tau_{M-d e d, k} *$ $\lambda(g)_{k} *\left(r_{M, k}-r_{T}\right)+m_{k}+\left(1-\tau_{P-\text { ded, }}-\kappa\right) * \tau_{p, k}-\pi_{k}$

and the user cost facing tax filers who claim the standard deduction becomes:

$$
U C_{\text {Standard, } k}=\left(1-\tau_{y}\right) *\left[\left(1-\lambda(g)_{k}\right) * r_{T}+\beta\right]+r_{T} * \lambda(g)_{k}+m_{k}+(1-\kappa) * \tau_{P, k}-\pi_{k} .
$$

Metro-level parameters are employed for MTRs, LTV ratios, maintenance rates, property tax rates and anticipated price appreciation. ${ }^{7}$ Each market's simulated price is therefore responsive to an array of local market conditions.

This framework forms the basis by which we estimate price changes that result from policy changes to the MID in each market. Working from the identity: 


$$
\frac{R_{k}}{P_{k}}=U C_{k}
$$

to simulate price changes, we first impute rents $\left(R_{k}\right)$ for each market by multiplying the reported average prices $\left(P_{k}\right)$ by the user cost $\left(U C_{k}\right)$. In the first set of simulations, the new home price resulting from any change in MID policy is found by solving:

$$
P_{k}^{*}=\frac{R_{k}}{U C_{k}^{*}}
$$

where $R_{k}$ is the imputed rent found using current policy data, $U C_{k}^{*}$ is the user cost reflecting an MID policy change, and $P_{k}{ }^{*}$ is the home price resulting from the policy change. In this instance we assume that the price elasticity of supply is zero - that is, when changes to the MID change the user cost, the homeowner capitalizes the savings (or additional expense) into the home price.

In order to derive an elasticity-sensitive estimate of the price effect, we need measures of the price elasticities of demand and supply. We use Saiz's (2010) metropolitan-area estimates of supply elasticities. ${ }^{8}$ Estimates of the price elasticity of demand for housing vary greatly. Identification is complicated by the fact that housing is a differentiated product with unobserved local amenities over which heterogeneous households sort. Studies over the last several decades identify estimates ranging from near perfect inelasticity to greater than unit elasticity. ${ }^{9}$

We take a middle-of-the-road view of demand elasticity by selecting a value of 0.8 applied to all metropolitan areas in the study. It should be noted that if this demand elasticity is higher (lower) than the true value, then our simulation would understate (overstate) the price change resulting from MID reform. We use this demand elasticity to determine what share of the price change in the model above occurs in a model with elastic demand and supply. This share is given by:

$$
\frac{\epsilon_{D}}{\epsilon_{D}+\epsilon_{S}}
$$

where $\epsilon$ is the price elasticity of demand (D) or supply (S) respectively. The new price resulting from a policy change is then given by:

$$
P_{k}^{*}=P_{k}+\left(\frac{R_{k}}{U C_{k}^{*}}-P_{k}\right) \frac{\epsilon_{D}}{\epsilon_{D}+\epsilon_{S, k}}
$$

When $\epsilon_{S, k}=0$, expression (11) is equal to one for any value of demand elasticity, and the right-hand side of Eq. (12) collapses to the special case in Eq. (10). For supply elasticities greater than zero, the new price is moderated by the relative strength of the elasticity of supply and demand. As supply elasticity rises, the price effect of a policy change falls. ${ }^{10}$

Both Glaeser et al. (2006) and Green et al. (2005) describe the complication to modeling housing supply due to its durable nature. When demand rises, housing starts are able to respond positively to the extent that land is available for development. When demand falls, however, the existing stock is not destroyed in order to reduce quantity. Consequently housing supply is likely kinked, with low supply elasticity in the face of price decreases, and higher elasticity in the face of price increases. We interpret our inelastic and elastic results accordingly: the inelastic simulations reflect the immediate impact to the market, particularly under policies that result in falling demand, whereas the elastic simulations reflect the long-run price effects. 


\section{Data}

We use MSA-level aggregates to parameterize the user cost model. The two primary sources of data are the 2011 Internal Revenue Service (IRS) Statistics of Income (SOI) and the 2011 American Housing Survey (AHS).

\subsection{IRS SOI data}

The IRS makes available ZIP code-level summaries of individual income tax variables from personal income tax returns. The full 2011 data file contains statistics for 32,515 ZIP codes. While nominally selfreported, these data derive directly from personal income tax returns. Each item in the report includes the number of tax filers that report the item and the gross amount reported in each ZIP code. From these raw data we construct the variables: average adjusted gross income (AGI), average alternative minimum tax (AMT), average taxable income, proportion of tax filers claiming dependents, proportion of tax filers filing jointly, and proportion of tax filers claiming the MID. In addition, we match the average taxable incomes and the proportion of tax filers filing jointly to the marginal income tax rates in 2011 in order to construct an average marginal tax rate (MTR) for each ZIP code. The ZIP code-level marginal tax rate is calculated as:

$$
\operatorname{AvgMTR}_{j}=\operatorname{Joint}_{j} * \operatorname{MTR}_{\text {joint }}\left(\text { Taxable }_{j}\right)+\left(1-\text { Joint }_{j}\right) * \operatorname{MTR}_{\text {single }}\left(\text { Taxable }_{j}\right)
$$

where Joint $j$ is the percent of tax filers who are married and filing jointly in ZIP code $j, M_{\text {TRoint }}()$ is a function that returns the MTR for married couples filing jointly with a taxable income of Taxable $_{j}$; and $M T R_{\text {single }}()$ is a function that returns the MTR for single tax filers. ${ }^{11}$

\subsection{AHS data}

The AHS is a survey administered by the US Census Bureau on behalf of the Department of Housing and Urban Development. Both its format and scope have changed over time. The 2011 survey includes two samples of owner-occupying households: a national sample comprised of 186,448 households, with a subsample of 105,665 households across 29 focus cities, called the metro sample. Some observations are missing either state identifiers, on which our estimation results rely, metro identifiers, on which our simulations rely, or both. Additionally, some households are missing one or more key variable of interest, or are renters (rather than owner occupiers). We use observations of owner occupied households in which the LTV ratio, household income, number of minors in the home, annual maintenance expenditure, annual property tax expenditure, home value and the mortgage interest rate are present.

Because data are self-reported, certain anomalies occur. The data also contains top- or bottom-codes for certain variables. We exclude any observation that has one or more of the following conditions: a top- or bottom-code on a variable of interest, an imputed (rather than reported) value, a home price of less than $\$ 1000$, a reported annual appreciation rate of greater than one hundred percent or less than minus fifty percent, and either no property tax ${ }^{12}$ or property tax in excess of ten percent ${ }^{13}$ of the home value. We also exclude the top percentile of reported LTV ratios because that variable is particularly sensitive to misstatement of the home value. Of the 24,109 households otherwise suitable for estimation, 2643 are excluded due to one or more of these anomalies. Of the 28,327 households otherwise suitable for our simulations, 3182 are excluded for one or more of these anomalies. 


\subsection{Additional data}

In addition to these data sources, we obtain two measures of historic price appreciation: a proprietary repeat-sales index constructed by CoreLogic, and the publicly available Zillow Home Value Index. We use the county-level aggregate of each index, and average those measures at the MSA level using number of owner-occupied households in 2010 in each county as weights. ${ }^{14}$

We also draw from multiple sources to obtain tax policy data at the state level. We obtain availability of the MID on state income taxes from the TAXSIM model hosted by the National Bureau of Economic Research. ${ }^{15}$ Top MTRs at the state level are obtained from the Tax Foundation.

Other parameters that do not vary according to geography include a risk-free rate of return whose proxy is the ten-year interest rate on treasury bonds, the federal capital gains tax rate, and a risk premium on housing adopted from Poterba and Sinai (2011). Summary statistics for the parameters used in the simulation are shown in Table 1.

Table 1. User cost parameter values.

\begin{tabular}{|c|c|c|c|c|c|c|c|}
\hline Parameter & Source & $\begin{array}{c}\text { Reporting } \\
\text { level }\end{array}$ & Minimum & Maximum & Average & Min. city & Max. city \\
\hline $\begin{array}{l}\text { Percent of } \\
\text { itemizing tax } \\
\text { filers }\end{array}$ & SOI & ZIP code & $20.8 \%$ & $50.9 \%$ & $36.8 \%$ & Miami-FL & $\begin{array}{l}\text { Wash., } \\
\text { D.C. }\end{array}$ \\
\hline $\begin{array}{c}\text { Loan to value } \\
\text { ratio }\end{array}$ & AHS & Household & $58.1 \%$ & $103.5 \%$ & $74.4 \%$ & San Francisco & Phoenix \\
\hline $\begin{array}{l}\text { State + federal } \\
\text { subsidy rate }\end{array}$ & SOI & ZIP code & $16.2 \%$ & $32.5 \%$ & $22.8 \%$ & Miami-FL & San Jose \\
\hline Property tax rate & AHS & Household & $0.7 \%$ & $2.4 \%$ & $1.4 \%$ & Birmingham & Detroit \\
\hline $\begin{array}{c}\text { Mortgage } \\
\text { interest rate }\end{array}$ & AHS & Household & $4.8 \%$ & $6.1 \%$ & $5.3 \%$ & San Jose & Houston \\
\hline $\begin{array}{c}\text { Price } \\
\text { appreciation rate }\end{array}$ & CoreLogic & County & $-1.7 \%$ & $6.5 \%$ & $3.1 \%$ & Detroit & New York \\
\hline $\begin{array}{c}\text { Price } \\
\text { appreciation rate }\end{array}$ & Zillow & County & $-2.1 \%$ & $6.6 \%$ & $3.3 \%$ & Detroit & New York \\
\hline $\begin{array}{l}\text { Housing risk } \\
\text { premium }\end{array}$ & $\begin{array}{l}\text { Poterba \& } \\
\text { Sinai }\end{array}$ & National & $2.0 \%$ & $2.0 \%$ & $2.0 \%$ & - & - \\
\hline $\begin{array}{c}\text { Capital gains tax } \\
\text { rate }\end{array}$ & IRS & National & $15.0 \%$ & $15.0 \%$ & $15.0 \%$ & - & - \\
\hline $\begin{array}{l}\text { Risk free rate of } \\
\text { return }\end{array}$ & Treasury & National & $3.5 \%$ & $3.5 \%$ & $3.5 \%$ & - & - \\
\hline
\end{tabular}

Household, ZIP code and County levels indicate original areal units which are aggregated to the metro area level using weighted averages. ZIP codes are weighted by the number of tax filers. Counties are weighted by the number of owner occupied households in the American Community Survey 2010-2012 wave. AHS households are weighted using AHSnational weights. SOI data come from the Internal Revenue Service's Statistics of Income division. AHS data come from the US Census Bureau's American Housing Survey. Minimum, Maximum and Averages are for the sample of 34 cities included in this study. State + federal subsidy rates are computed using average MTRs as computed in Eq. (13) plus the top state MTR.

\section{Empirical estimates of behavioral parameters}

We take into account two behavioral parameters with regard to the MID: how sensitive are itemization and debt financing to the tax subsidy. If tax filers have sufficient itemizable deductions, they will choose to itemize rather than claim the standard deduction; because the MID is a part of itemized deductions, a change in the MID affects the likelihood a household will itemize deductions at all. Likewise, the MID reduces the cost of debt financing, which may influence the degree to which 
households use debt financing to pay for housing. Using variation in the availability of the MID at the state level, ${ }^{16}$ we estimate the sensitivity of the percent of tax filers who itemize deductions $\left(/(g)_{j}\right)$ and of LTV ratios $\left(\lambda(g)_{i}\right)$ to the MSR of the MID. ${ }^{17}$ This is done with data from SOI and AHS and follows a similar method to that used in Hanson and Martin (2014) to estimate sensitivity of MID claims to the MSR. We use both weighted least squares (WLS) and Instrumental Variables (IV) to estimate these relationships.

\subsection{Itemization and the MID}

The basic WLS specification to estimate the impact of the MID on the rate of tax itemization is:

$$
\text { Itemizers }_{j}=\beta_{0}+\beta_{1} \text { TopMTR }_{s} * M I D_{s}+\boldsymbol{Z}_{\boldsymbol{j}}^{\prime} \boldsymbol{\beta}+\varepsilon
$$

where Itemizers $j$ is the percent of tax filers who itemize returns in ZIP code $j$, TopMTR $_{s} * M_{I} D_{s}$ is the state $(s)$ top marginal income tax rate interacted with an indicator equal to one if the state allows the mortgage interest deduction on state tax returns, and $Z_{j}$ is a set of controls including adjusted gross income, the percent of returns claiming dependents, the percent of filings that are joint, the amount of alternative minimum tax paid and the percent of filers who pay it in each ZIP code. The regression is weighted by the square root of the number of tax returns in each ZIP code. Standard errors reflect the White (1980) correction for heteroskedasticity. The coefficient of interest is $B_{1}$, which reflects the change in the percent of itemizers in a ZIP code resulting from a one percentage-point increase in the MSR.

We also estimate the equations above using an instrumental variable framework. Our instrument for MID availability is an indicator of whether a state adopts the full itemization schedule from the federal tax code into its own state income tax code. This instrument is designed to resolve endogeneity that may arise from unobserved political influence by homeowners seeking preferential tax subsidies in their state tax policy. Such targeted homeowner lobbying would most likely result in a state adopting the MID in isolation of other tax breaks. Six states have adopted the MID in this manner, while 24 offer the MID reflexively as a result of allowing all federal itemizations on state income tax returns. ${ }^{18}$ The instrument therefore captures as compliers MID claims resulting from state availability of the MID that does not arise from preferential treatment to homeowners by way of an a la carte MID deduction.

A straightforward application of the instrument would be to fit $M I D_{j}$, the indicator of MID deductibility, by regressing $M I D_{j}$ on UseFed $_{s}$, the instrument described above. Because the outcome of interest is not $M I D_{j}$ but instead the MSR at the state level (captured by the interaction TopMTR ${ }^{*} M I D_{s}$ ), we construct

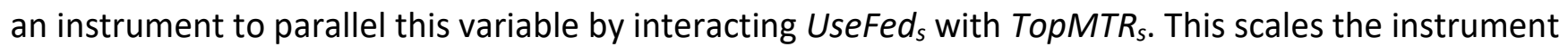
so that the fitted values of $T_{0 p M T R_{s}} * M I D_{s}$ translate linearly to the second stage. The first stage, then, is:

$$
\operatorname{TopMTR}_{s} * \text { MID }_{s}=b_{0}+b_{1} \text { TopMTR }_{s} * \text { UseFed }_{s}+\mathbf{Z}_{j}^{\prime} \boldsymbol{B}+\varepsilon
$$

while the second stage becomes:

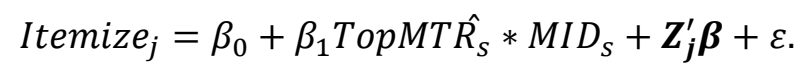

The first two columns of Table 2 show the first-stage results of this regression applied to the SOI data. The fit of the instrument is statistically significant at the one-percent level.

Table 2. First stage results of instrumental variables specification. 


\begin{tabular}{|c|c|c|c|c|}
\hline \multirow[b]{2}{*}{ Variables: } & \multicolumn{2}{|c|}{ IRS } & \multicolumn{2}{|c|}{ AHS } \\
\hline & No controls & Controls & No controls & Controls \\
\hline \multirow[t]{2}{*}{ Instrument: TopMTR $_{s} *$ UseFed $_{s}$} & $0.9206 * * *$ & $0.9168 * * *$ & $0.9640 * * *$ & $0.9640 * * *$ \\
\hline & $(0.0031)$ & $(0.0045)$ & $(0.0029)$ & $(0.00292)$ \\
\hline \multirow[t]{2}{*}{ Average adjusted gross income (in $\$ 1000$ s) } & & $-0.0081 * * *$ & & \\
\hline & & $(0.0008)$ & & \\
\hline \multirow[t]{2}{*}{ Household salary (in \$1000s) } & & & & 0.0002 \\
\hline & & & & $(0.0001)$ \\
\hline \multirow[t]{2}{*}{ Percent of households claiming dependents } & & 0.0003 & & \\
\hline & & $(0.0006)$ & & \\
\hline \multirow[t]{2}{*}{ Number of minors in household } & & & & 0.0102 \\
\hline & & & & $(0.0105)$ \\
\hline \multirow[t]{2}{*}{ Percent of households filing jointly } & & $0.0174 * * *$ & & \\
\hline & & $(0.0012)$ & & \\
\hline \multirow[t]{2}{*}{ Average alternative minimum tax paid (in $\$ 1000$ s) } & & $0.1243 * * *$ & & \\
\hline & & $(0.0164)$ & & \\
\hline \multirow[t]{2}{*}{ Percent of households paying alternative minimum tax } & & 0.0022 & & \\
\hline & & (0.0045) & & \\
\hline \multirow[t]{2}{*}{ Constant } & $0.6573 * * *$ & -0.1387 & $0.3251 * * *$ & $0.3080 * * *$ \\
\hline & $(0.0257)$ & $(0.0875)$ & $(0.0264)$ & $(0.0263)$ \\
\hline Observations & 26,622 & 12,849 & 22,612 & 22,612 \\
\hline F-Test & 87,652 & 41,452 & 108,525 & 108,966 \\
\hline
\end{tabular}

The fitted variable is the state income tax rate in percentage points interacted with an indicator equal to 1 if the state allows the mortgage interest deduction (MID) on state tax returns (i.e. TopMTR $* M I D_{s}$ ). The first two columns contain observations from ZIP codes in the IRS Statistics of Income (SOI) in 2011, and the fitted values are used in Table 3. The second two columns contain observations from households in the American Housing Survey (AHS) in 2011, and the fitted values are used in Table 4. Robust standard errors in parentheses. $* * * p<0.01, * * p<0.05$, and $* p<0.1$.

Table 3 presents results for the sensitivity of the percent of tax filers who itemize to the MSR. The variable of interest is the indicator of MID availability crossed with the state's top MTR. The reported coefficient is the change in percent of itemizers resulting from a one percentage point increase in the MSR. The first two specifications report WLS estimates. In the uncontrolled regression, a one percentage-point increase in the MSR leads to an increase in itemizers by 0.55 percentage points. Based on this result, if tax filers were offered an additional dollar back through the channel of itemized deductions for each $\$ 100$ of mortgage interest they pay, the rate of itemization would rise from $30.66 \%$ of tax filers (the constant in the first specification) to $31.21 \%$. When controlling for covariates, the effect of a one percentage point increase in the MSR on the proportion of filers who itemize falls to 0.52 percentage points.

Table 3. Impact of the MID on the proportion of itemizing tax filers.

\begin{tabular}{|c|c|c|c|c|}
\hline \multirow[b]{2}{*}{ Variable } & \multicolumn{2}{|c|}{ WLS } & \multicolumn{2}{|c|}{ IV } \\
\hline & No controls & Controls & No controls & Controls \\
\hline \multirow[t]{2}{*}{$\operatorname{TopMTR}_{s} * M I D_{s}$} & $0.5487^{* * *}$ & $0.5237 * * *$ & $0.6724 * * *$ & $0.6252 * * *$ \\
\hline & $(0.0328)$ & $(0.0248)$ & $(0.0366)$ & $(0.0270)$ \\
\hline \multirow[t]{2}{*}{ Average adjusted gross income (in $\$ 1000$ s) } & & $0.0486 * * *$ & & $0.0551 * * *$ \\
\hline & & $(0.0072)$ & & $(0.0075)$ \\
\hline \multirow[t]{2}{*}{ Percent of households claiming dependents } & & $-0.1183^{* * *}$ & & $-0.1214^{* * *}$ \\
\hline & & $(0.0046)$ & & $(0.0048)$ \\
\hline \multirow[t]{2}{*}{ Percent of households filing jointly } & & $0.4740 * * *$ & & $0.4713^{* * *}$ \\
\hline & & $(0.0088)$ & & $(0.0090)$ \\
\hline Average alternative minimum tax paid (in $\$ 1000$ s) & & $-0.8933^{* * *}$ & & $-0.9810 * * *$ \\
\hline
\end{tabular}




\begin{tabular}{|c|l|l|l|l|}
\hline \multirow{2}{*}{ Percent of households paying alternative minimum tax } & & $(0.1071)$ & & $(0.1185)$ \\
\cline { 2 - 5 } & & $1.5343^{* * *}$ & & $1.4921^{* * *}$ \\
\hline Constant & $30.6593 * * *$ & $(0.0474)$ & & $(0.0485)$ \\
\hline & $(0.1836)$ & $(0.6720)$ & $(0.1882)$ & $(0.70)$ \\
\hline Observations & 27,787 & 13,420 & 26,622 & 12,849 \\
\hline R-squared & 0.0267 & 0.6743 & & \\
\hline
\end{tabular}

The dependent variable (proportion of itemizing tax filers) is given in percentage points, i.e. $30.0 \%=30.0$. Regressions are weighted by the square root of the number of tax returns in each ZIP code. Robust standard errors in parentheses. ${ }^{* * *} \mathrm{p}<0.01, * * \mathrm{p}<0.05$, and $* p<0.1$.

The next two specifications employ instrumental variables. The IV results in Table 3 show slightly stronger effects of the MID on the proportion of itemizers than those in the WLS specifications, with coefficients of 0.67 and 0.63 for the uncontrolled and controlled regressions respectively. ${ }^{19}$

\subsection{LTV and the MID}

The second behavioral parameter we estimate is the sensitivity of LTV ratios to the availability of the MID. The regression is similar to that given in Eq. (14), but with the dependent variable being the LTV ratio of household $i . Z_{i}^{\prime}$ is a set of controls including the household's salary and the number of minors living in the household:

$$
L T V_{i}=\beta_{0}+\beta_{1} T_{\text {TopMTR }} * M I D_{i}+\boldsymbol{Z}_{i}^{\prime} \boldsymbol{\beta}+\varepsilon .
$$

The regression is weighted by the AHS national weights, which reflect how representative each household is of the national population using census controls. Standard errors are again corrected for heteroskedasticity. $b_{1}$ reflects the change in LTV ratios resulting from a one percentage-point increase in the MSR.

Table 4 describes the sensitivity of LTV ratios to the MSR. Specifications follow the same pattern as in Table 3. In the uncontrolled regression, a one percentage-point increase in the MSR leads to a (statistically insignificant) increase in the LTV ratio of 0.18 percentage points. Based on this result, if tax filers were offered an additional dollar back through the channel of itemized deductions for each $\$ 100$ of mortgage interest they pay, the LTV ratio would rise from $74.94 \%$ (the constant in the first specification) to $75.15 \%$.

Table 4. Impact of the MID on the loan-to-value (LTV) ratio of homeowners.

\begin{tabular}{|c|c|c|c|c|}
\hline \multirow[b]{2}{*}{ Variable } & \multicolumn{2}{|c|}{ WLS } & \multicolumn{2}{|c|}{ IV } \\
\hline & No controls & Controls & No controls & Controls \\
\hline \multirow[t]{2}{*}{$\operatorname{TopMTR}_{s} * M I D_{s}$} & 0.1762 & $0.2111^{*}$ & $0.2366^{* *}$ & $0.2790 * *$ \\
\hline & $(0.1162)$ & $(0.1150)$ & $(0.1190)$ & $(0.1179)$ \\
\hline \multirow[t]{2}{*}{ Household salary (in $\$ 1000$ s) } & & -0.0091 & & -0.0098 \\
\hline & & $(0.0072)$ & & $(0.0073)$ \\
\hline \multirow[t]{2}{*}{ Number of minors in household } & & $5.7867 * * *$ & & $5.8762 * * *$ \\
\hline & & $(0.4616)$ & & $(0.4766)$ \\
\hline \multirow[t]{2}{*}{ Constant } & $74.9385 * * *$ & $71.2925 * * *$ & $75.0498 * * *$ & $71.3536 * * *$ \\
\hline & $(0.7877)$ & $(0.9767)$ & $(0.7941)$ & $(0.9872)$ \\
\hline Observations & 24,141 & 24,141 & 22,612 & 22,612 \\
\hline R-squared & 0.0003 & 0.0195 & & \\
\hline
\end{tabular}

The dependent variable (LTV Ratio) is given in percentage points, i.e. $30.0 \%=30.0$. Regressions are weighted by the household weight provided by the Census. Robust standard errors in parentheses. ${ }^{* * *} p<0.01, * * p<0.05$, and $*_{p}<0.1$. 
When controlling for household income and number of children present, the coefficient rises slightly to 0.21 and becomes significant at the ten percent level.

We apply the same IV strategy as in Eq. (15), but with LTV as the dependent variable and the AHS household as the unit of analysis. ${ }^{20}$ The next two columns in Table 4 show the results of this strategy. As in Table 3, they also reflect somewhat higher sensitivity of LTV ratios to the MID, with coefficients of 0.24 and 0.28 for the uncontrolled and controlled regressions respectively. These are significant at the five percent level.

\subsection{Implementing the estimates}

Taking these empirical estimates to the user cost model for policy simulation requires the choice of a functional form for $I(g)_{j}$ and $\lambda(g)_{i}$. We use the linear form:

$$
I(g)_{k}=\alpha_{k}+\beta_{\text {itemize }} * g
$$

where in each market $j$, the percent of itemizers in the market who would itemize without any MID subsidy is given by $\alpha_{k}$, the MSR is given by $g$, and the slope $\beta_{\text {itemize }}$ is the coefficient of interest in Table 3. For instance, if ten percent of tax filers in market $k$ would itemize deductions without any subsidy, and the policy under consideration is a twenty percent mortgage interest deduction for itemizing tax filers, then the function predicts the proportion of itemizing tax filers as:

$$
I(g)_{k}=0.10+\beta_{\text {itemize }} * 0.20
$$

Similarly, the LTV function is:

$$
\lambda(g)_{k}=\gamma_{k}+\beta_{L T V} * g
$$

where $\gamma_{k}$ is the average LTV ratio that would obtain in a market without any subsidy, and the slope $B_{L T V}$ is the coefficient of interest in Table 4.

\section{Policy change and simulation results}

With the behavioral parameters in hand and data characterizing each metropolitan area housing market, we proceed to simulate policy changes to mortgage interest tax deductibility. We consider three scenarios: eliminating the MID, converting the MID to a fifteen percent refundable tax credit, and capping the deduction at a rate lower than the highest federal MTR. For each simulated outcome under the three policy scenarios presented here we show how the behavioral parameters $I(g)$ and $\lambda(g)$ affect results. We refer to results with no behavioral changes as "static" simulation and those that incorporate the behavioral change parameters as "dynamic".

If Congress were to eliminate the MID, it would remove the tax incentive to debt finance altogether. Mathematically, this is equivalent to setting $\tau_{M-\text { ded }, j}=0+$ TopMTR $_{j} * M I D_{j} *\left(1-\right.$ UseFed $\left._{j}\right)$ in the $U C_{\text {itemize }}$ model from Eq. (7). ${ }^{21} U C_{\text {standard }}$ in Eq. (8) experiences no change. This policy would reduce the benefits of itemizing deductions and raise the user cost for itemizing households.

If instead Congress converted the MID from a deduction at the taxpayer's MTR to a refundable fifteen percent tax credit, the incentive to finance housing debt and to itemize deductions would become diluted for many current itemizers (specifically those in marginal tax brackets exceeding fifteen percent). It would also extend the tax benefit received from debt financing to those who do not itemize. A conversion to such a tax credit is equivalent to setting 
$\tau_{M-\text { ded }, k}=0.15+$ TopMTR $_{s} * M I D_{s} *\left(1-\right.$ UseFed $\left._{s}\right)$ in the $U C_{\text {itemize }}$ model of Eq. (7), setting $\tau_{M}$ - ded , $k=0.15$ in the $U C_{\text {standard }}$ model of Eq. (8), and extending the $U C_{\text {standard }}$ model as follows:

(21) $U C_{\text {standard,k }}=\left[1-\left\{\tau_{M-d e d, k} * \lambda(g)_{k}+\tau_{y} *\left(1-\lambda(g)_{k}\right)\right\}\right] * r_{T}+r_{T} \lambda(g)_{k}+\left(1-\tau_{y}\right) * \beta-$ $\tau_{M-d e d, k} * \lambda(g)_{k} *\left(r_{M, k}-r_{T}\right)+m_{k}+(1-\kappa) * \tau_{p, k}-\pi_{k}$.

Note that the only differences between the cost for itemizers and non-itemizers are the property tax deduction and the MID at the state level that remain available to itemizers. Non-itemizers gain the cost savings of the mortgage interest credit.

Because the deduction is converted to a refundable credit, only those tax filers who would itemize with no marginal incentive due to the MID will continue to itemize. This means that, in the dynamic simulation of a tax credit, $g=0$ in $I(g)_{k}$. The tax credit does, however, still incentivize debt financing, leaving $g=0.15$ in $\lambda(g)_{k}$.

Another policy alternative is to cap the MID at a rate lower than the highest MTR (35\% in 2011 and $39.6 \%$ presently). This has the effect of blunting the deduction for wealthier borrowers while leaving it intact for middle- and lower-income borrowers. Hanson and Martin (2014) explore the impact of a cap of $28 \%$, a policy endorsed by President Obama (Timiraos, 2012). We simulate a cap of fifteen percent.

22 The impact of such a cap on the user cost model is simply to set

$\tau_{M-\text { ded }, k}=\min \left\{M T R_{k}, c a p\right\}+T_{0 p M T R_{s}} * M I D_{s}$ in $U C_{i t e m i z e}$ where the lower of either the taxpayer's MTR or the legal cap becomes the rate at which mortgage interest is deducted at the federal level. Any state that presently offers the MID is presumed to continue doing so. As in the full elimination scenario, $U C_{\text {standard }}$ remains unchanged. Examining a fifteen percent cap allows a direct comparison of the differing effects of a cap on the deduction versus offering a refundable credit of equal size.

\subsection{Simulation results}

\subsubsection{Itemization and LTV changes}

Table 5 reports the percent of itemizers and the LTV ratios in each city in our sample under each of the three policies: eliminating the MID, converting it to a fifteen percent credit, or capping it at a rate of fifteen percent. There is significant local variation in present itemizing behavior: the city with the fewest itemizing tax filers is Miami-Fort Lauderdale at 21\%; the city with the most itemizing tax filers is Washington, D.C., with 51\%. LTV ratios show a similar level of variation: San Francisco, CA has the lowest average LTV ratio at 58\%, while Phoenix, AZ has the highest at $103 \%$.

Table 5. Behavioral parameter changes resulting from MID policy changes.

\begin{tabular}{|c|c|c|c|c|c|c|c|c|c|c|c|}
\hline \multirow[b]{3}{*}{ City } & \multirow{2}{*}{\multicolumn{2}{|c|}{$\begin{array}{c}\text { Current } \\
\text { parameter } \\
\text { values }\end{array}$}} & \multicolumn{9}{|c|}{ Parameter values in dynamic simulations } \\
\hline & & & \multicolumn{3}{|c|}{ Eliminate the MID } & \multicolumn{3}{|c|}{$15 \%$ credit } & \multicolumn{3}{|c|}{$15 \%$ cap } \\
\hline & $\begin{array}{c}\text { Itemize } \\
\text { rs }\end{array}$ & LTV & $\begin{array}{c}\text { Itemize } \\
\text { rs }\end{array}$ & $\begin{array}{c}\text { LTV }_{\text {item }} \\
\text { ize }\end{array}$ & $\begin{array}{c}\text { LTV }_{\text {stand }} \\
\text { ard }\end{array}$ & $\begin{array}{c}\text { Itemize } \\
\text { rs }\end{array}$ & $\begin{array}{c}\text { LTV }_{\text {item }} \\
\text { ize }\end{array}$ & $\begin{array}{c}\text { LTV }_{\text {stand }} \\
\quad \text { ard }\end{array}$ & $\begin{array}{c}\text { Itemize } \\
\text { rs }\end{array}$ & $\begin{array}{c}\text { LTV }_{\text {item }} \\
\text { ize }\end{array}$ & $\begin{array}{c}\text { LTV }_{\text {stand }} \\
\text { ard }\end{array}$ \\
\hline $\begin{array}{l}\text { Atlanta, } \\
\text { GA }\end{array}$ & $40.7 \%$ & $\begin{array}{l}91.1 \\
\%\end{array}$ & $24.6 \%$ & $84.4 \%$ & $91.1 \%$ & $24.6 \%$ & $88.6 \%$ & $88.6 \%$ & $38.7 \%$ & $90.3 \%$ & $91.1 \%$ \\
\hline $\begin{array}{c}\text { Baltimore, } \\
\text { MD }\end{array}$ & $47.1 \%$ & $\begin{array}{l}71.1 \\
\%\end{array}$ & $30.5 \%$ & $64.2 \%$ & $71.1 \%$ & $30.5 \%$ & $68.4 \%$ & $68.4 \%$ & $44.3 \%$ & $69.9 \%$ & $71.1 \%$ \\
\hline $\begin{array}{c}\text { Birmingha } \\
\text { m, AL }\end{array}$ & $37.0 \%$ & $\begin{array}{l}70.5 \\
\%\end{array}$ & $21.8 \%$ & $64.2 \%$ & $70.5 \%$ & $21.8 \%$ & $68.3 \%$ & $68.3 \%$ & $35.2 \%$ & $69.7 \%$ & $70.5 \%$ \\
\hline
\end{tabular}




\begin{tabular}{|c|c|c|c|c|c|c|c|c|c|c|c|}
\hline $\begin{array}{c}\text { Boston, } \\
\text { MA }\end{array}$ & $41.2 \%$ & $\begin{array}{l}58.3 \\
\%\end{array}$ & $26.5 \%$ & $52.2 \%$ & $58.3 \%$ & $26.5 \%$ & $56.4 \%$ & $56.4 \%$ & $36.6 \%$ & $56.4 \%$ & $58.3 \%$ \\
\hline $\begin{array}{c}\text { Charlotte, } \\
\text { NC }\end{array}$ & $41.0 \%$ & $\begin{array}{l}74.3 \\
\%\end{array}$ & $23.6 \%$ & $67.1 \%$ & $74.3 \%$ & $23.6 \%$ & $71.3 \%$ & $71.3 \%$ & $38.9 \%$ & $73.4 \%$ & $74.3 \%$ \\
\hline Chicago, IL & $39.0 \%$ & $\begin{array}{l}66.6 \\
\%\end{array}$ & $26.3 \%$ & $61.3 \%$ & $66.6 \%$ & $26.3 \%$ & $65.5 \%$ & $65.5 \%$ & $36.4 \%$ & $65.5 \%$ & $66.6 \%$ \\
\hline $\begin{array}{c}\text { Cincinnati, } \\
\text { OH }\end{array}$ & $36.8 \%$ & $\begin{array}{l}74.3 \\
\%\end{array}$ & $24.3 \%$ & $69.2 \%$ & $74.3 \%$ & $24.3 \%$ & $73.3 \%$ & $73.3 \%$ & $34.3 \%$ & $73.3 \%$ & $74.3 \%$ \\
\hline $\begin{array}{c}\text { Cleveland, } \\
\text { OH }\end{array}$ & $34.9 \%$ & $\begin{array}{l}74.0 \\
\%\end{array}$ & $22.7 \%$ & $68.9 \%$ & $74.0 \%$ & $22.7 \%$ & $73.1 \%$ & $73.1 \%$ & $32.8 \%$ & $73.1 \%$ & $74.0 \%$ \\
\hline $\begin{array}{c}\text { Columbus, } \\
\mathrm{OH}\end{array}$ & $37.4 \%$ & $\begin{array}{l}73.2 \\
\%\end{array}$ & $25.1 \%$ & $68.1 \%$ & $73.2 \%$ & $25.1 \%$ & $72.2 \%$ & $72.2 \%$ & $35.1 \%$ & $72.2 \%$ & $73.2 \%$ \\
\hline $\begin{array}{c}\text { Dallas- } \\
\text { Fort } \\
\text { Worth, TX }\end{array}$ & $29.7 \%$ & $\begin{array}{l}68.3 \\
\%\end{array}$ & $17.0 \%$ & $63.0 \%$ & $68.3 \%$ & $17.0 \%$ & $67.2 \%$ & $67.2 \%$ & $27.1 \%$ & $67.2 \%$ & $68.3 \%$ \\
\hline $\begin{array}{l}\text { Denver, } \\
\text { CO }\end{array}$ & $39.9 \%$ & $\begin{array}{l}72.7 \\
\%\end{array}$ & $23.6 \%$ & $66.0 \%$ & $72.7 \%$ & $23.6 \%$ & $70.1 \%$ & $70.1 \%$ & $36.7 \%$ & $71.4 \%$ & $72.7 \%$ \\
\hline $\begin{array}{l}\text { Detroit, } \\
\text { MI }\end{array}$ & $33.2 \%$ & $\begin{array}{l}98.5 \\
\%\end{array}$ & $21.2 \%$ & $93.5 \%$ & $98.5 \%$ & $21.2 \%$ & $97.7 \%$ & $97.7 \%$ & $31.2 \%$ & $97.7 \%$ & $98.5 \%$ \\
\hline $\begin{array}{c}\text { Houston, } \\
\text { TX }\end{array}$ & $28.6 \%$ & $\begin{array}{l}64.5 \\
\%\end{array}$ & $15.6 \%$ & $59.1 \%$ & $64.5 \%$ & $15.6 \%$ & $63.3 \%$ & $63.3 \%$ & $25.6 \%$ & $63.3 \%$ & $64.5 \%$ \\
\hline $\begin{array}{c}\text { Indianapol } \\
\text { is, IN }\end{array}$ & $33.6 \%$ & $\begin{array}{l}77.4 \\
\%\end{array}$ & $21.3 \%$ & $72.2 \%$ & $77.4 \%$ & $21.3 \%$ & $76.4 \%$ & $76.4 \%$ & $31.3 \%$ & $76.4 \%$ & $77.4 \%$ \\
\hline $\begin{array}{c}\text { Los } \\
\text { Angeles, } \\
\text { CA }\end{array}$ & $33.6 \%$ & $\begin{array}{l}67.4 \\
\%\end{array}$ & $14.7 \%$ & $59.6 \%$ & $67.4 \%$ & $14.7 \%$ & $63.7 \%$ & $63.7 \%$ & $31.7 \%$ & $66.6 \%$ & $67.4 \%$ \\
\hline $\begin{array}{l}\text { Memphis, } \\
\text { TN }\end{array}$ & $28.2 \%$ & $\begin{array}{l}76.0 \\
\%\end{array}$ & $16.3 \%$ & $71.1 \%$ & $76.0 \%$ & $16.3 \%$ & $75.3 \%$ & $75.3 \%$ & $26.4 \%$ & $75.3 \%$ & $76.0 \%$ \\
\hline $\begin{array}{c}\text { Miami- } \\
\text { Fort } \\
\text { Lauderdal } \\
\text { e, FL }\end{array}$ & $20.8 \%$ & $\begin{array}{l}91.6 \\
\%\end{array}$ & $9.9 \%$ & $87.1 \%$ & $91.6 \%$ & $9.9 \%$ & $91.3 \%$ & $91.3 \%$ & $20.0 \%$ & $91.3 \%$ & $91.6 \%$ \\
\hline $\begin{array}{c}\text { Minneapo } \\
\text { lis-St Paul, } \\
\text { MN }\end{array}$ & $44.7 \%$ & $\begin{array}{l}74.9 \\
\%\end{array}$ & $26.1 \%$ & $67.2 \%$ & $74.9 \%$ & $26.1 \%$ & $71.4 \%$ & $71.4 \%$ & $41.4 \%$ & $73.6 \%$ & $74.9 \%$ \\
\hline $\begin{array}{c}\text { New York, } \\
\text { NY }\end{array}$ & $36.5 \%$ & $\begin{array}{l}61.9 \\
\%\end{array}$ & $18.6 \%$ & $54.5 \%$ & $61.9 \%$ & $18.6 \%$ & $58.7 \%$ & $58.7 \%$ & $33.7 \%$ & $60.7 \%$ & $61.9 \%$ \\
\hline $\begin{array}{c}\text { Philadelph } \\
\text { ia, PA }\end{array}$ & $41.0 \%$ & $\begin{array}{l}60.7 \\
\%\end{array}$ & $28.0 \%$ & $55.3 \%$ & $60.7 \%$ & $28.0 \%$ & $59.4 \%$ & $59.4 \%$ & $38.0 \%$ & $59.4 \%$ & $60.7 \%$ \\
\hline $\begin{array}{c}\text { Phoenix, } \\
\text { AZ }\end{array}$ & $34.2 \%$ & $\begin{array}{l}103.5 \\
\%\end{array}$ & $19.3 \%$ & $97.3 \%$ & $103.5 \%$ & $19.3 \%$ & $\begin{array}{l}101.5 \\
\%\end{array}$ & $101.5 \%$ & $32.5 \%$ & $\begin{array}{l}102.7 \\
\%\end{array}$ & $103.5 \%$ \\
\hline $\begin{array}{l}\text { Pittsburgh } \\
\text {, PA }\end{array}$ & $28.4 \%$ & $\begin{array}{l}61.4 \\
\%\end{array}$ & $15.9 \%$ & $56.2 \%$ & $61.4 \%$ & $15.9 \%$ & $60.4 \%$ & $60.4 \%$ & $26.0 \%$ & $60.4 \%$ & $61.4 \%$ \\
\hline $\begin{array}{l}\text { Portland, } \\
\text { OR }\end{array}$ & $42.4 \%$ & $\begin{array}{l}73.4 \\
\%\end{array}$ & $26.0 \%$ & $66.6 \%$ & $73.4 \%$ & $26.0 \%$ & $70.8 \%$ & $70.8 \%$ & $40.0 \%$ & $72.4 \%$ & $73.4 \%$ \\
\hline $\begin{array}{c}\text { Providenc } \\
\text { e, RI }\end{array}$ & $36.3 \%$ & $\begin{array}{l}74.8 \\
\%\end{array}$ & $23.9 \%$ & $69.7 \%$ & $74.8 \%$ & $23.9 \%$ & $73.8 \%$ & $73.8 \%$ & $34.0 \%$ & $73.8 \%$ & $74.8 \%$ \\
\hline $\begin{array}{c}\text { Riverside, } \\
\text { CA }\end{array}$ & $35.4 \%$ & $\begin{array}{l}100.2 \\
\%\end{array}$ & $17.9 \%$ & $93.0 \%$ & $100.2 \%$ & $17.9 \%$ & $97.2 \%$ & $97.2 \%$ & $34.9 \%$ & $\begin{array}{l}100.0 \\
\%\end{array}$ & $100.2 \%$ \\
\hline $\begin{array}{c}\text { Sacrament } \\
\text { o, CA }\end{array}$ & $38.0 \%$ & $\begin{array}{l}88.2 \\
\%\end{array}$ & $18.9 \%$ & $80.2 \%$ & $88.2 \%$ & $18.9 \%$ & $84.4 \%$ & $84.4 \%$ & $35.9 \%$ & $87.3 \%$ & $88.2 \%$ \\
\hline $\begin{array}{c}\text { San Diego, } \\
\text { CA }\end{array}$ & $36.7 \%$ & $\begin{array}{l}72.0 \\
\%\end{array}$ & $17.3 \%$ & $63.9 \%$ & $72.0 \%$ & $17.3 \%$ & $68.1 \%$ & $68.1 \%$ & $34.3 \%$ & $71.0 \%$ & $72.0 \%$ \\
\hline
\end{tabular}




\begin{tabular}{|c|c|c|c|c|c|c|c|c|c|c|c|}
\hline $\begin{array}{c}\text { San } \\
\text { Francisco, } \\
\text { CA }\end{array}$ & $42.5 \%$ & $\begin{array}{l}58.1 \\
\%\end{array}$ & $20.9 \%$ & $49.2 \%$ & $58.1 \%$ & $20.9 \%$ & $53.4 \%$ & $53.4 \%$ & $37.9 \%$ & $56.2 \%$ & $58.1 \%$ \\
\hline $\begin{array}{c}\text { San Jose, } \\
\text { CA }\end{array}$ & $43.7 \%$ & $\begin{array}{l}65.9 \\
\%\end{array}$ & $21.8 \%$ & $56.8 \%$ & $65.9 \%$ & $21.8 \%$ & $61.0 \%$ & $61.0 \%$ & $38.8 \%$ & $63.9 \%$ & $65.9 \%$ \\
\hline $\begin{array}{c}\text { Seattle, } \\
\text { WA }\end{array}$ & $39.4 \%$ & $\begin{array}{l}64.0 \\
\%\end{array}$ & $25.1 \%$ & $58.1 \%$ & $64.0 \%$ & $25.1 \%$ & $62.3 \%$ & $62.3 \%$ & $35.2 \%$ & $62.3 \%$ & $64.0 \%$ \\
\hline $\begin{array}{l}\text { St. Louis, } \\
\text { MO }\end{array}$ & $36.8 \%$ & $\begin{array}{l}71.9 \\
\%\end{array}$ & $21.9 \%$ & $65.7 \%$ & $71.9 \%$ & $21.9 \%$ & $69.9 \%$ & $69.9 \%$ & $34.3 \%$ & $70.9 \%$ & $71.9 \%$ \\
\hline Tampa, FL & $23.5 \%$ & $\begin{array}{l}89.5 \\
\%\end{array}$ & $11.9 \%$ & $84.7 \%$ & $89.5 \%$ & $11.9 \%$ & $88.9 \%$ & $88.9 \%$ & $22.0 \%$ & $88.9 \%$ & $89.5 \%$ \\
\hline $\begin{array}{l}\text { Virginia } \\
\text { Beach, VA }\end{array}$ & $38.1 \%$ & $\begin{array}{l}72.4 \\
\%\end{array}$ & $22.4 \%$ & $65.9 \%$ & $72.4 \%$ & $22.4 \%$ & $70.1 \%$ & $70.1 \%$ & $36.3 \%$ & $71.7 \%$ & $72.4 \%$ \\
\hline $\begin{array}{l}\text { Washingt } \\
\text { on, D.C. }\end{array}$ & $50.9 \%$ & $\begin{array}{l}66.4 \\
\%\end{array}$ & $32.3 \%$ & $58.7 \%$ & $66.4 \%$ & $32.3 \%$ & $62.9 \%$ & $62.9 \%$ & $46.4 \%$ & $64.5 \%$ & $66.4 \%$ \\
\hline
\end{tabular}

The first two columns reflect the present percent of itemizing tax filers and average LTV ratios for each metro area. Subsequent columns identify the value the variable takes in the dynamic version of each simulation, where household behavior is allowed to adjust.

Table 5 also reports the simulated change to these parameters under each of the three policies considered. Our empirically estimated behavioral parameters predict that eliminating the MID would result in itemization rates falling by as much as 22 percentage points in San Jose, and by as little as 11 percentage points in Miami-Fort Lauderdale. Eliminating the MID results in LTV ratios falling for itemizers by as much as 9 percentage points in San Jose, and by as little as 5 percentage points in Memphis, TN. The change away from itemizing is identical under the policy converting the MID to a fifteen percent credit, whereas the effect on LTV ratios is lessened (LTV ratios remain higher). The LTV ratio effect is also spread across itemizers and standard deduction tax filers, since the incentive to debt finance is not restricted to itemizers under the switch to a tax credit. Changes are more muted under the policy where the MID is simply capped at $15 \%$, but itemization rates still fall somewhat in all metros.

\subsubsection{Price changes}

Table 6 reports the simulated price changes for 34 selected cities under the policy of MID elimination. Four scenarios are presented for each policy: supply inelastic scenarios assume the price elasticity of supply is zero; supply elastic scenarios use the demand and supply elasticities described in section II. For each of the above we show both static prices, where no changes to itemizing or LTV ratios occur, and dynamic prices, where each of these parameters is allowed to adjust by the factors estimated in Table 3, Table 4 respectively.

Table 6. Simulated effects on home prices of eliminating the mortgage interest deduction.

\begin{tabular}{|c|c|c|c|c|c|c|c|c|c|}
\hline \multirow[b]{3}{*}{ City } & \multirow{3}{*}{$\begin{array}{l}\text { Current avg. } \\
\text { Price }\end{array}$} & \multicolumn{4}{|c|}{ Supply inelastic } & \multicolumn{4}{|c|}{ Supply elastic } \\
\hline & & \multicolumn{2}{|c|}{ Static } & \multicolumn{2}{|c|}{ Dynamic } & \multicolumn{2}{|c|}{ Static } & \multicolumn{2}{|c|}{ Dynamic } \\
\hline & & Price & $\begin{array}{c}\% \\
\text { Change }\end{array}$ & Price & $\begin{array}{c}\% \\
\text { Change }\end{array}$ & Price & $\begin{array}{c}\% \\
\text { Change }\end{array}$ & Price & $\begin{array}{c}\% \\
\text { Change }\end{array}$ \\
\hline Atlanta, GA & 189.6 & 174.0 & $-8.2 \%$ & 172.8 & $-8.8 \%$ & 185.9 & $-2.0 \%$ & 185.6 & $-2.0 \%$ \\
\hline Baltimore, MD & 259.4 & 231.5 & $-10.7 \%$ & 229.6 & $-11.5 \%$ & 248.4 & $-4.2 \%$ & 247.7 & $-4.2 \%$ \\
\hline Birmingham, AL & 184.4 & 173.1 & $-6.2 \%$ & 172.6 & $-6.4 \%$ & 181.4 & $-1.7 \%$ & 181.2 & $-1.7 \%$ \\
\hline Boston, MA & 394.9 & 368.9 & $-6.6 \%$ & 366.0 & $-7.3 \%$ & 382.4 & $-3.2 \%$ & 381.0 & $-3.2 \%$ \\
\hline Charlotte, NC & 199.5 & 183.4 & $-8.1 \%$ & 182.0 & $-8.8 \%$ & 196.2 & $-1.7 \%$ & 195.9 & $-1.7 \%$ \\
\hline Chicago, IL & 263.2 & 251.8 & $-4.3 \%$ & 249.9 & $-5.1 \%$ & 257.6 & $-2.2 \%$ & 256.6 & $-2.2 \%$ \\
\hline Cincinnati, OH & 173.3 & 165.7 & $-4.4 \%$ & 164.7 & $-4.9 \%$ & 171.4 & $-1.1 \%$ & 171.2 & $-1.1 \%$ \\
\hline
\end{tabular}




\begin{tabular}{|c|c|c|c|c|c|c|c|c|c|}
\hline Cleveland, $\mathrm{OH}$ & 158.1 & 152.4 & $-3.6 \%$ & 151.5 & $-4.2 \%$ & 155.6 & $-1.6 \%$ & 155.2 & $-1.6 \%$ \\
\hline Columbus, $\mathrm{OH}$ & 184.6 & 176.9 & $-4.2 \%$ & 175.8 & $-4.8 \%$ & 182.9 & $-1.0 \%$ & 182.6 & $-1.0 \%$ \\
\hline Dallas-Fort Worth, TX & 188.8 & 182.1 & $-3.6 \%$ & 180.7 & $-4.3 \%$ & 187.0 & $-1.0 \%$ & 186.7 & $-1.0 \%$ \\
\hline Denver, CO & 271.4 & 250.2 & $-7.8 \%$ & 249.0 & $-8.2 \%$ & 264.1 & $-2.7 \%$ & 263.7 & $-2.7 \%$ \\
\hline Detroit, MI & 157.6 & 151.5 & $-3.9 \%$ & 150.6 & $-4.4 \%$ & 155.2 & $-1.5 \%$ & 154.9 & $-1.5 \%$ \\
\hline Houston, TX & 188.0 & 180.8 & $-3.9 \%$ & 179.3 & $-4.7 \%$ & 186.2 & $-1.0 \%$ & 185.8 & $-1.0 \%$ \\
\hline Indianapolis, IN & 171.3 & 163.9 & $-4.3 \%$ & 163.4 & $-4.6 \%$ & 170.0 & $-0.7 \%$ & 170.0 & $-0.7 \%$ \\
\hline Los Angeles, CA & 479.3 & 438.1 & $-8.6 \%$ & 432.9 & $-9.7 \%$ & 456.2 & $-4.8 \%$ & 453.3 & $-4.8 \%$ \\
\hline Memphis, TN & 145.8 & 140.7 & $-3.5 \%$ & 140.0 & $-3.9 \%$ & 144.2 & $-1.1 \%$ & 144.0 & $-1.1 \%$ \\
\hline $\begin{array}{c}\text { Miami-Fort } \\
\text { Lauderdale, FL }\end{array}$ & 202.7 & 196.3 & $-3.2 \%$ & 195.6 & $-3.5 \%$ & 199.1 & $-1.8 \%$ & 198.6 & $-1.8 \%$ \\
\hline $\begin{array}{c}\text { Minneapolis-St Paul, } \\
\text { MN }\end{array}$ & 235.0 & 211.6 & $-9.9 \%$ & 209.2 & $-11.0 \%$ & 226.7 & $-3.5 \%$ & 225.8 & $-3.5 \%$ \\
\hline New York, NY & 435.9 & 394.1 & $-9.6 \%$ & 388.3 & $-10.9 \%$ & 414.5 & $-4.9 \%$ & 411.5 & $-4.9 \%$ \\
\hline Philadelphia, PA & 275.8 & 260.1 & $-5.7 \%$ & 258.1 & $-6.4 \%$ & 270.7 & $-1.9 \%$ & 270.0 & $-1.9 \%$ \\
\hline Phoenix, AZ & 191.7 & 178.5 & $-6.9 \%$ & 177.6 & $-7.3 \%$ & 187.3 & $-2.3 \%$ & 187.0 & $-2.3 \%$ \\
\hline Pittsburgh, PA & 157.4 & 152.7 & $-3.0 \%$ & 151.6 & $-3.7 \%$ & 155.5 & $-1.2 \%$ & 155.1 & $-1.2 \%$ \\
\hline Portland, OR & 293.7 & 269.9 & $-8.1 \%$ & 267.0 & $-9.1 \%$ & 283.5 & $-3.5 \%$ & 282.3 & $-3.5 \%$ \\
\hline Providence, RI & 246.4 & 233.4 & $-5.3 \%$ & 231.9 & $-5.9 \%$ & 242.1 & $-1.8 \%$ & 241.6 & $-1.8 \%$ \\
\hline Riverside, CA & 247.5 & 225.3 & $-9.0 \%$ & 223.2 & $-9.8 \%$ & 237.3 & $-4.1 \%$ & 236.3 & $-4.1 \%$ \\
\hline Sacramento, CA & 290.5 & 262.5 & $-9.6 \%$ & 259.7 & $-10.6 \%$ & - & - & - & - \\
\hline San Diego, CA & 447.5 & 404.1 & $-9.7 \%$ & 399.6 & $-10.7 \%$ & 423.9 & $-5.3 \%$ & 421.4 & $-5.3 \%$ \\
\hline San Francisco, CA & 823.7 & 739.8 & $-10.2 \%$ & 730.9 & $-11.3 \%$ & 777.7 & $-5.6 \%$ & 772.8 & $-5.6 \%$ \\
\hline San Jose, CA & 683.0 & 603.8 & $-11.6 \%$ & 595.5 & $-12.8 \%$ & 642.4 & $-5.9 \%$ & 638.2 & $-5.9 \%$ \\
\hline Seattle, WA & 376.1 & 351.3 & $-6.6 \%$ & 349.4 & $-7.1 \%$ & 364.3 & $-3.1 \%$ & 363.4 & $-3.1 \%$ \\
\hline St. Louis, MO & 172.0 & 162.8 & $-5.3 \%$ & 161.3 & $-6.2 \%$ & 169.7 & $-1.4 \%$ & 169.3 & $-1.4 \%$ \\
\hline Tampa, FL & 178.2 & 171.9 & $-3.5 \%$ & 171.2 & $-3.9 \%$ & 175.4 & $-1.6 \%$ & 175.1 & $-1.6 \%$ \\
\hline Virginia Beach, VA & 232.1 & 212.2 & $-8.6 \%$ & 210.8 & $-9.2 \%$ & 222.3 & $-4.2 \%$ & 221.6 & $-4.2 \%$ \\
\hline Washington, D.C. & 388.7 & 339.8 & $-12.6 \%$ & 336.1 & $-13.5 \%$ & 372.5 & $-4.2 \%$ & 371.3 & $-4.2 \%$ \\
\hline
\end{tabular}

Average home prices are in $\$ 1000$ s. Percent changes are the percent change in price from current prices as a result of policy change. Static simulations hold city-level itemization and debt-finance levels constant; dynamic simulations allow city-level itemization and debtfinance levels to vary according to the largest elasticity derived in Table 3, Table 4 respectively.

The first column reports the current average home price in each city. San Francisco has the highest average home price of $\$ 823,700$, and Memphis has the lowest of $\$ 145,800$. The next two columns report the simulated home price and the percent change from current home prices if the MID were eliminated under the assumptions of inelastic supply and static behavioral response. As a rule, prices would fall under this scenario, but the degree varies significantly depending on the city. At one extreme, Washington, D.C. would experience roughly a $13 \%$ drop in home prices. The most modest changes would occur in Pittsburgh, PA where prices would fall by only $3 \%$.

The next two columns report price changes under inelastic supply and dynamic behavioral response. The differences from the static simulation average about a percentage point of home value, but are as large as $\$ 8900$ in San Francisco. In each city the dynamic price change is greater than the static, reflecting the fact that households are allowed to optimize behavior on more dimensions in the dynamic model than in the static one.

The next four columns report price changes assuming that supply is elastic. The price effects are substantially moderated in these results, with decreases as high as $5.9 \%$ (San Jose) and as low as $0.7 \%$ (Indianapolis, IN). Cities with low supply elasticities reported in Saiz (2010) are those whose geographic land constraints make building more difficult. This is evident in the supply elastic simulations presented 
here, where differences are closest to their inelastic counterparts for coastal cities such as Miami-Fort Lauderdale, New York, NY, Boston, MA and all reported California cities except Sacramento, CA. ${ }^{23}$ Cities where the greatest difference from inelastic simulations occur include Indianapolis, Charlotte, NC, and Columbus, $\mathrm{OH}$.

Table 7 simulates the conversion of the MID from a tax deduction to a refundable tax credit of $15 \%$. The consequences of this policy vary significantly from city to city, but in most cases home prices increase rather than decrease. In general, this suggests that the price drop experienced by itemizers whose MTRs are above 15\% (and who therefore decrease demand for housing in the face of higher costs) is offset by capitalization from homeowners who now claim the new tax credit and to whom user costs have just become lower. Under the inelastic and static assumptions, all price changes are positive. Prices rise the most in Miami-Fort Lauderdale, by $13 \%$. In general, cities with few itemizers and low MTRs are likely to see greater price increases under this policy.

Table 7. Simulated effects on home prices of converting the mortgage interest deduction to a $15 \%$ credit.

\begin{tabular}{|c|c|c|c|c|c|c|c|c|c|}
\hline \multirow[b]{3}{*}{ City } & \multirow{3}{*}{$\begin{array}{l}\text { Current Avg. } \\
\text { Price }\end{array}$} & \multicolumn{4}{|c|}{ Supply inelastic } & \multicolumn{4}{|c|}{ Supply elastic } \\
\hline & & \multicolumn{2}{|c|}{ Static } & \multicolumn{2}{|c|}{ Dynamic } & \multicolumn{2}{|c|}{ Static } & \multicolumn{2}{|c|}{ Dynamic } \\
\hline & & Price & $\begin{array}{c}\% \\
\text { Change }\end{array}$ & Price & $\begin{array}{c}\% \\
\text { Change }\end{array}$ & Price & $\begin{array}{c}\% \\
\text { Change }\end{array}$ & Price & $\begin{array}{c}\% \\
\text { Change }\end{array}$ \\
\hline Atlanta, GA & 189.6 & 199.1 & $5.0 \%$ & 196.9 & $3.9 \%$ & 191.9 & $1.2 \%$ & 191.3 & $1.2 \%$ \\
\hline Baltimore, MD & 259.4 & 268.6 & $3.5 \%$ & 264.6 & $2.0 \%$ & 263.0 & $1.4 \%$ & 261.5 & $1.4 \%$ \\
\hline Birmingham, AL & 184.4 & 194.5 & $5.4 \%$ & 193.3 & $4.8 \%$ & 187.2 & $1.5 \%$ & 186.8 & $1.5 \%$ \\
\hline Boston, MA & 394.9 & 414.0 & $4.8 \%$ & 408.9 & $3.5 \%$ & 404.1 & $2.3 \%$ & 401.7 & $2.3 \%$ \\
\hline Charlotte, NC & 199.5 & 207.0 & $3.8 \%$ & 204.4 & $2.5 \%$ & 201.0 & $0.8 \%$ & 200.5 & $0.8 \%$ \\
\hline Chicago, IL & 263.2 & 276.2 & $4.9 \%$ & 273.4 & $3.9 \%$ & 269.7 & $2.4 \%$ & 268.3 & $2.4 \%$ \\
\hline Cincinnati, OH & 173.3 & 183.3 & $5.8 \%$ & 181.8 & $4.9 \%$ & 175.7 & $1.4 \%$ & 175.4 & $1.4 \%$ \\
\hline Cleveland, $\mathrm{OH}$ & 158.1 & 166.7 & $5.4 \%$ & 165.4 & $4.6 \%$ & 161.9 & $2.4 \%$ & 161.3 & $2.4 \%$ \\
\hline Columbus, $\mathrm{OH}$ & 184.6 & 194.6 & $5.4 \%$ & 193.0 & $4.6 \%$ & 186.9 & $1.2 \%$ & 186.5 & $1.2 \%$ \\
\hline Dallas-Fort Worth, TX & 188.8 & 201.2 & $6.5 \%$ & 199.2 & $5.5 \%$ & 192.2 & $1.8 \%$ & 191.6 & $1.8 \%$ \\
\hline Denver, CO & 271.4 & 284.6 & $4.9 \%$ & 282.0 & $3.9 \%$ & 275.9 & $1.7 \%$ & 275.0 & $1.7 \%$ \\
\hline Detroit, MI & 157.6 & 167.9 & $6.6 \%$ & 166.7 & $5.8 \%$ & 161.6 & $2.6 \%$ & 161.1 & $2.6 \%$ \\
\hline Houston, TX & 188.0 & 201.9 & $7.4 \%$ & 199.7 & $6.2 \%$ & 191.6 & $1.9 \%$ & 191.0 & $1.9 \%$ \\
\hline Indianapolis, IN & 171.3 & 183.0 & $6.8 \%$ & 182.1 & $6.3 \%$ & 173.2 & $1.1 \%$ & 173.1 & $1.1 \%$ \\
\hline Los Angeles, CA & 479.3 & 507.4 & $5.9 \%$ & 498.3 & $4.0 \%$ & 495.0 & $3.3 \%$ & 489.9 & $3.3 \%$ \\
\hline Memphis, TN & 145.8 & 157.2 & $7.8 \%$ & 156.2 & $7.1 \%$ & 149.3 & $2.4 \%$ & 149.0 & $2.4 \%$ \\
\hline $\begin{array}{c}\text { Miami-Fort } \\
\text { Lauderdale, FL }\end{array}$ & 202.7 & 228.5 & $12.7 \%$ & 227.3 & $12.1 \%$ & 217.4 & $7.3 \%$ & 216.8 & $7.3 \%$ \\
\hline $\begin{array}{c}\text { Minneapolis-St Paul, } \\
\text { MN }\end{array}$ & 235.0 & 240.7 & $2.4 \%$ & 236.5 & $0.7 \%$ & 237.0 & $0.9 \%$ & 235.5 & $0.9 \%$ \\
\hline New York, NY & 435.9 & 462.6 & $6.1 \%$ & 452.1 & $3.7 \%$ & 449.6 & $3.1 \%$ & 444.2 & $3.1 \%$ \\
\hline Philadelphia, PA & 275.8 & 291.2 & $5.6 \%$ & 287.9 & $4.4 \%$ & 280.9 & $1.8 \%$ & 279.8 & $1.8 \%$ \\
\hline Phoenix, AZ & 191.7 & 206.7 & $7.8 \%$ & 205.1 & $7.0 \%$ & 196.7 & $2.6 \%$ & 196.1 & $2.6 \%$ \\
\hline Pittsburgh, PA & 157.4 & 166.9 & $6.1 \%$ & 165.4 & $5.1 \%$ & 161.2 & $2.4 \%$ & 160.6 & $2.4 \%$ \\
\hline Portland, OR & 293.7 & 306.1 & $4.2 \%$ & 301.3 & $2.6 \%$ & 299.0 & $1.8 \%$ & 297.0 & $1.8 \%$ \\
\hline Providence, RI & 246.4 & 264.9 & $7.5 \%$ & 262.5 & $6.5 \%$ & 252.6 & $2.5 \%$ & 251.8 & $2.5 \%$ \\
\hline Riverside, CA & 247.5 & 263.9 & $6.6 \%$ & 260.3 & $5.2 \%$ & 255.0 & $3.1 \%$ & 253.4 & $3.1 \%$ \\
\hline Sacramento, CA & 290.5 & 303.2 & $4.4 \%$ & 298.4 & $2.7 \%$ & - & - & - & - \\
\hline San Diego, CA & 447.5 & 468.7 & $4.7 \%$ & 460.5 & $2.9 \%$ & 459.1 & $2.6 \%$ & 454.6 & $2.6 \%$ \\
\hline San Francisco, CA & 823.7 & 833.2 & $1.2 \%$ & 817.3 & $-0.8 \%$ & 828.9 & $0.6 \%$ & 820.2 & $0.6 \%$ \\
\hline San Jose, CA & 683.0 & 688.2 & $0.7 \%$ & 673.5 & $-1.4 \%$ & 685.7 & $0.4 \%$ & 678.2 & $0.4 \%$ \\
\hline
\end{tabular}




\begin{tabular}{|c|l|l|l|l|l|l|l|l|l|}
\hline Seattle, WA & 376.1 & 398.6 & $6.0 \%$ & 394.8 & $5.0 \%$ & 386.8 & $2.8 \%$ & 385.0 & $2.8 \%$ \\
\hline St. Louis, MO & 172.0 & 180.6 & $5.0 \%$ & 178.3 & $3.7 \%$ & 174.2 & $1.3 \%$ & 173.6 & $1.3 \%$ \\
\hline Tampa, FL & 178.2 & 197.6 & $10.9 \%$ & 196.6 & $10.4 \%$ & 186.8 & $4.9 \%$ & 186.4 & $4.9 \%$ \\
\hline Virginia Beach, VA & 232.1 & 248.1 & $6.9 \%$ & 245.2 & $5.6 \%$ & 240.0 & $3.4 \%$ & 238.6 & $3.4 \%$ \\
\hline Washington, D.C. & 388.7 & 392.1 & $0.9 \%$ & 384.6 & $-1.1 \%$ & 389.9 & $0.3 \%$ & 387.4 & $0.3 \%$ \\
\hline
\end{tabular}

Average home prices are in $\$ 1000$ s. Percent changes are the percent change in price from current prices as a result of policy change. Static simulations hold city-level itemization and debt-finance levels constant; dynamic simulations allow city-level itemization and debtfinance levels to vary according to the largest elasticity derived in Table 3, Table 4 respectively.

The dynamic simulation follows a similar pattern of rising prices in most cities, but with more modest gains. San Francisco, San Jose, and Washington, D.C. experience small home price declines, suggesting that the decreased demand due to itemizers outweighs the increase demand due to standard filers once behavioral response is taken into account. This is consistent with the relatively high proportion of itemizers in each of these cities $(43,44$ and $51 \%$ respectively) combined with relatively high MTRs (not reported). As in Table 6, the elastic scenarios report smaller price effects in general, with higher price changes clustering in coastal cities.

Table 8 simulates the consequences of capping the MID at a rate of $15 \%$. This policy would decrease home values in all cities, but again at significantly different rates. In the static inelastic model, Riverside, CA would experience only a $0.3 \%$ decline in prices; at the high end, prices in Washington, D.C. would fall by $3.4 \%$. Price decreases are once again more dramatic in the dynamic scenario, and are muted in the elastic scenarios.

Table 8. Simulated effects on home prices of capping the mortgage interest deduction at $15 \%$.

\begin{tabular}{|c|c|c|c|c|c|c|c|c|c|}
\hline \multirow[b]{3}{*}{ City } & \multirow{3}{*}{$\begin{array}{l}\text { Current Avg. } \\
\text { Price }\end{array}$} & \multicolumn{4}{|c|}{ Supply inelastic } & \multicolumn{4}{|c|}{ Supply elastic } \\
\hline & & \multicolumn{2}{|c|}{ Static } & \multicolumn{2}{|c|}{ Dynamic } & \multicolumn{2}{|c|}{ Static } & \multicolumn{2}{|c|}{ Dynamic } \\
\hline & & Price & $\begin{array}{c}\% \\
\text { Change }\end{array}$ & Price & $\begin{array}{c}\% \\
\text { Change }\end{array}$ & Price & $\begin{array}{c}\% \\
\text { Change }\end{array}$ & Price & $\begin{array}{c}\% \\
\text { Change }\end{array}$ \\
\hline Atlanta, GA & 189.6 & 187.5 & $-1.1 \%$ & 186.5 & $-1.6 \%$ & 189.1 & $-0.3 \%$ & 188.8 & $-0.3 \%$ \\
\hline Baltimore, MD & 259.4 & 254.1 & $-2.0 \%$ & 251.9 & $-2.9 \%$ & 257.3 & $-0.8 \%$ & 256.5 & $-0.8 \%$ \\
\hline Birmingham, AL & 184.4 & 183.0 & $-0.8 \%$ & 182.4 & $-1.1 \%$ & 184.1 & $-0.2 \%$ & 183.9 & $-0.2 \%$ \\
\hline Boston, MA & 394.9 & 386.3 & $-2.2 \%$ & 382.8 & $-3.1 \%$ & 390.8 & $-1.1 \%$ & 389.1 & $-1.1 \%$ \\
\hline Charlotte, NC & 199.5 & 197.4 & $-1.1 \%$ & 196.3 & $-1.6 \%$ & 199.1 & $-0.2 \%$ & 198.8 & $-0.2 \%$ \\
\hline Chicago, IL & 263.2 & 260.8 & $-0.9 \%$ & 259.7 & $-1.4 \%$ & 262.0 & $-0.5 \%$ & 261.5 & $-0.5 \%$ \\
\hline Cincinnati, OH & 173.3 & 171.8 & $-0.9 \%$ & 171.1 & $-1.3 \%$ & 172.9 & $-0.2 \%$ & 172.7 & $-0.2 \%$ \\
\hline Cleveland, $\mathrm{OH}$ & 158.1 & 157.1 & $-0.6 \%$ & 156.6 & $-1.0 \%$ & 157.7 & $-0.3 \%$ & 157.4 & $-0.3 \%$ \\
\hline Columbus, $\mathrm{OH}$ & 184.6 & 183.1 & $-0.8 \%$ & 182.5 & $-1.2 \%$ & 184.3 & $-0.2 \%$ & 184.1 & $-0.2 \%$ \\
\hline Dallas-Fort Worth, TX & 188.8 & 187.4 & $-0.8 \%$ & 186.6 & $-1.2 \%$ & 188.5 & $-0.2 \%$ & 188.2 & $-0.2 \%$ \\
\hline Denver, CO & 271.4 & 267.0 & $-1.6 \%$ & 265.1 & $-2.3 \%$ & 269.9 & $-0.5 \%$ & 269.2 & $-0.5 \%$ \\
\hline Detroit, MI & 157.6 & 156.6 & $-0.6 \%$ & 156.1 & $-0.9 \%$ & 157.2 & $-0.3 \%$ & 157.0 & $-0.3 \%$ \\
\hline Houston, TX & 188.0 & 186.4 & $-0.9 \%$ & 185.3 & $-1.4 \%$ & 187.6 & $-0.2 \%$ & 187.3 & $-0.2 \%$ \\
\hline Indianapolis, IN & 171.3 & 169.8 & $-0.8 \%$ & 169.3 & $-1.2 \%$ & 171.0 & $-0.1 \%$ & 170.9 & $-0.1 \%$ \\
\hline Los Angeles, CA & 479.3 & 474.9 & $-0.9 \%$ & 471.7 & $-1.6 \%$ & 476.8 & $-0.5 \%$ & 475.1 & $-0.5 \%$ \\
\hline Memphis, TN & 145.8 & 145.0 & $-0.6 \%$ & 144.5 & $-0.9 \%$ & 145.5 & $-0.2 \%$ & 145.4 & $-0.2 \%$ \\
\hline $\begin{array}{c}\text { Miami-Fort } \\
\text { Lauderdale, FL }\end{array}$ & 202.7 & 202.2 & $-0.2 \%$ & 201.9 & $-0.4 \%$ & 202.4 & $-0.1 \%$ & 202.3 & $-0.1 \%$ \\
\hline $\begin{array}{c}\text { Minneapolis-St Paul, } \\
\text { MN }\end{array}$ & 235.0 & 230.6 & $-1.9 \%$ & 228.3 & $-2.8 \%$ & 233.4 & $-0.7 \%$ & 232.6 & $-0.7 \%$ \\
\hline New York, NY & 435.9 & 428.8 & $-1.6 \%$ & 424.3 & $-2.7 \%$ & 432.3 & $-0.8 \%$ & 430.0 & $-0.8 \%$ \\
\hline Philadelphia, PA & 275.8 & 272.1 & $-1.4 \%$ & 270.5 & $-1.9 \%$ & 274.6 & $-0.4 \%$ & 274.1 & $-0.4 \%$ \\
\hline Phoenix, AZ & 191.7 & 190.1 & $-0.9 \%$ & 189.3 & $-1.3 \%$ & 191.1 & $-0.3 \%$ & 190.9 & $-0.3 \%$ \\
\hline
\end{tabular}




\begin{tabular}{|c|c|c|c|c|c|c|c|c|c|}
\hline Pittsburgh, PA & 157.4 & 156.5 & $-0.6 \%$ & 155.9 & $-1.0 \%$ & 157.0 & $-0.2 \%$ & 156.8 & $-0.2 \%$ \\
\hline Portland, OR & 293.7 & 290.0 & $-1.3 \%$ & 288.1 & $-1.9 \%$ & 292.1 & $-0.5 \%$ & 291.3 & $-0.5 \%$ \\
\hline Providence, RI & 246.4 & 243.9 & $-1.0 \%$ & 242.8 & $-1.5 \%$ & 245.6 & $-0.3 \%$ & 245.2 & $-0.3 \%$ \\
\hline Riverside, CA & 247.5 & 246.8 & $-0.3 \%$ & 246.4 & $-0.4 \%$ & 247.2 & $-0.1 \%$ & 247.0 & $-0.1 \%$ \\
\hline Sacramento, CA & 290.5 & 287.2 & $-1.1 \%$ & 285.1 & $-1.8 \%$ & - & - & - & - \\
\hline San Diego, CA & 447.5 & 441.8 & $-1.3 \%$ & 438.1 & $-2.1 \%$ & 444.4 & $-0.7 \%$ & 442.4 & $-0.7 \%$ \\
\hline San Francisco, CA & 823.7 & 804.4 & $-2.3 \%$ & 793.1 & $-3.7 \%$ & 813.1 & $-1.3 \%$ & 806.9 & $-1.3 \%$ \\
\hline San Jose, CA & 683.0 & 663.7 & $-2.8 \%$ & 652.9 & $-4.4 \%$ & 673.1 & $-1.4 \%$ & 667.6 & $-1.4 \%$ \\
\hline Seattle, WA & 376.1 & 368.5 & $-2.0 \%$ & 365.7 & $-2.8 \%$ & 372.5 & $-1.0 \%$ & 371.1 & $-1.0 \%$ \\
\hline St. Louis, MO & 172.0 & 170.4 & $-0.9 \%$ & 169.5 & $-1.4 \%$ & 171.6 & $-0.2 \%$ & 171.4 & $-0.2 \%$ \\
\hline Tampa, FL & 178.2 & 177.3 & $-0.5 \%$ & 176.8 & $-0.7 \%$ & 177.8 & $-0.2 \%$ & 177.6 & $-0.2 \%$ \\
\hline Virginia Beach, VA & 232.1 & 229.7 & $-1.0 \%$ & 228.5 & $-1.5 \%$ & 230.9 & $-0.5 \%$ & 230.3 & $-0.5 \%$ \\
\hline Washington, D.C. & 388.7 & 375.5 & $-3.4 \%$ & 370.1 & $-4.8 \%$ & 384.4 & $-1.1 \%$ & 382.5 & $-1.1 \%$ \\
\hline
\end{tabular}

Average home prices are in $\$ 1000$ s. Percent changes are the percent change in price from current prices as a result of policy change. Static simulations hold city-level itemization and debt-finance levels constant; dynamic simulations allow city-level itemization and debtfinance levels to vary according to the largest elasticity derived in Table 3, Table 4 respectively.

\subsubsection{Sensitivity analysis}

In addition to our primary simulation results, we conduct a series of sensitivity analyses to simulate prices under a set of alternative parameter assumptions. We consider four alternative sets of assumptions that deviate from those described above: 1) we use an alternate measure of historic home price inflation (Zillow's Home Value Index); we interpret local property tax to be either 2) purely an excise $\operatorname{tax}(\kappa=0)$ or 3 ) purely a benefit $\operatorname{tax}(\kappa=1)$; and 4) we assume the risk premium placed on housing assets is zero, rather than $2 \%$. In each case all other parameters remain as they are in the basic simulation. We apply each alternative to the inelastic dynamic scenario in which the MID is eliminated. Cases 1-4 are straightforward substitutions of parameters as described.

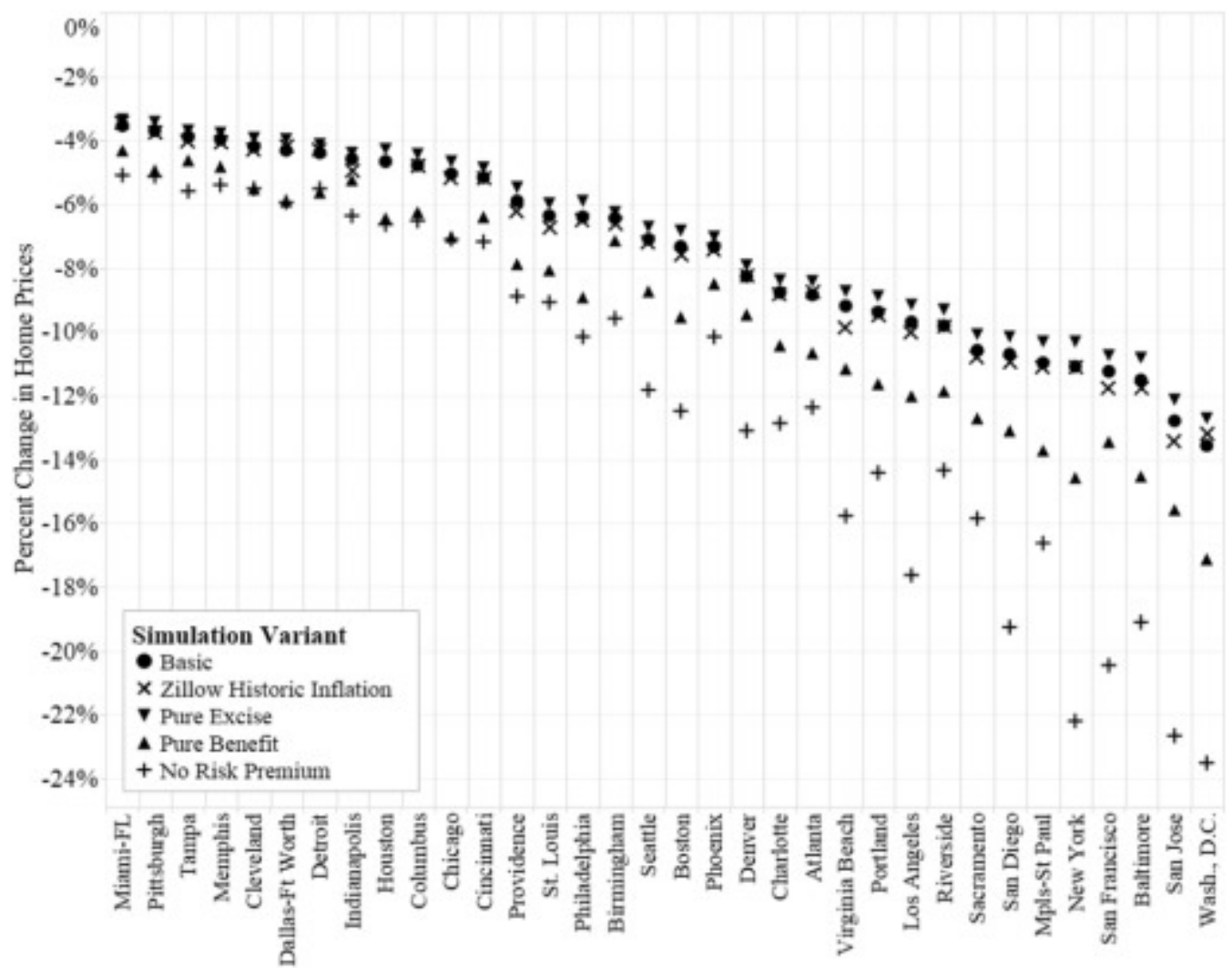

Fig. 1. Price changes from eliminating the MID under alternate simulation assumptions. 
In the basic case, city-level price effects of eliminating the MID range from decreases of 3.5 to $13.5 \%$. Fig. 1 plots these price changes, in the "Basic" series. In the first case described above, historic price appreciation is measured using Zillow's Home Value Index for all homes over the 13 previous years. This is in place of CoreLogic's proprietary repeat-sales index in the same geographies and time frame. There are modest differences between the two indices, and their effects on the model are reflected in the Zillow Historic Inflation series of Fig. 1. The Zillow simulation also appears in column 2 of Table 9, alongside the basic case for reference.

The basic simulation refers to the simulated percent change in average house price resulting from eliminating the mortgage interest deduction (MID) with dynamic adjustments and a price elasticity of supply equal to zero, repeated from Table 6, column 5. The Zillow Historic Inflation scenario uses the Zillow Home Value Index for all homes in place of the CoreLogic Home Price Index. The Pure Excise scenario assumes property taxes are purely excise taxes; the Pure Benefit scenario assumes they are pure benefit taxes. The No Risk Premium scenario assumes there is no risk premium to homeownership over a risk-free asset. In each variant all other parameters are equivalent to the basic simulation in column one.

Table 9. Sensitivity analysis of home price changes to alternative parameter assumptions.

\begin{tabular}{|c|c|c|c|c|c|}
\hline City & Basic & Zillow Historic Inflation & Pure Excise & Pure Benefit & No Risk Premium \\
\hline Atlanta, GA & $-8.8 \%$ & $-8.8 \%$ & $-8.4 \%$ & $-10.7 \%$ & $-12.4 \%$ \\
\hline Baltimore, MD & $-11.5 \%$ & $-11.8 \%$ & $-10.8 \%$ & $-14.5 \%$ & $-19.1 \%$ \\
\hline Birmingham, AL & $-6.4 \%$ & $-6.6 \%$ & $-6.3 \%$ & $-7.2 \%$ & $-9.6 \%$ \\
\hline Boston, MA & $-7.3 \%$ & $-7.6 \%$ & $-6.8 \%$ & $-9.5 \%$ & $-12.5 \%$ \\
\hline Charlotte, NC & $-8.8 \%$ & $-8.8 \%$ & $-8.4 \%$ & $-10.4 \%$ & $-12.9 \%$ \\
\hline Chicago, IL & $-5.1 \%$ & $-5.2 \%$ & $-4.7 \%$ & $-7.0 \%$ & $-7.1 \%$ \\
\hline Cincinnati, $\mathrm{OH}$ & $-5.2 \%$ & $-5.2 \%$ & $-4.9 \%$ & $-6.4 \%$ & $-7.2 \%$ \\
\hline Cleveland, $\mathrm{OH}$ & $-4.2 \%$ & $-4.3 \%$ & $-3.9 \%$ & $-5.5 \%$ & $-5.5 \%$ \\
\hline Columbus, $\mathrm{OH}$ & $-4.8 \%$ & $-4.8 \%$ & $-4.4 \%$ & $-6.3 \%$ & $-6.5 \%$ \\
\hline Dallas-Fort Worth, TX & $-4.3 \%$ & $-4.2 \%$ & $-4.0 \%$ & $-5.9 \%$ & $-5.9 \%$ \\
\hline Denver, CO & $-8.2 \%$ & $-8.2 \%$ & $-7.9 \%$ & $-9.5 \%$ & $-13.1 \%$ \\
\hline Detroit, MI & $-4.4 \%$ & $-4.3 \%$ & $-4.1 \%$ & $-5.6 \%$ & $-5.5 \%$ \\
\hline Houston, TX & $-4.7 \%$ & - & $-4.3 \%$ & $-6.4 \%$ & $-6.6 \%$ \\
\hline Indianapolis, IN & $-4.6 \%$ & $-5.0 \%$ & $-4.4 \%$ & $-5.2 \%$ & $-6.4 \%$ \\
\hline Los Angeles, CA & $-9.7 \%$ & $-10.0 \%$ & $-9.1 \%$ & $-12.0 \%$ & $-17.6 \%$ \\
\hline Memphis, TN & $-4.0 \%$ & $-4.1 \%$ & $-3.8 \%$ & $-4.8 \%$ & $-5.4 \%$ \\
\hline Miami-Fort Lauderdale, FL & $-3.5 \%$ & $-3.4 \%$ & $-3.3 \%$ & $-4.3 \%$ & $-5.1 \%$ \\
\hline Minneapolis-St Paul, MN & $-11.0 \%$ & $-11.1 \%$ & $-10.3 \%$ & $-13.7 \%$ & $-16.6 \%$ \\
\hline New York, NY & $-11.1 \%$ & $-11.1 \%$ & $-10.3 \%$ & $-14.6 \%$ & $-22.2 \%$ \\
\hline Philadelphia, PA & $-6.4 \%$ & $-6.5 \%$ & $-5.9 \%$ & $-8.9 \%$ & $-10.1 \%$ \\
\hline Phoenix, AZ & $-7.3 \%$ & $-7.4 \%$ & $-7.0 \%$ & $-8.5 \%$ & $-10.2 \%$ \\
\hline Pittsburgh, PA & $-3.7 \%$ & $-3.7 \%$ & $-3.4 \%$ & $-4.9 \%$ & $-5.1 \%$ \\
\hline Portland, OR & $-9.4 \%$ & $-9.5 \%$ & $-8.9 \%$ & $-11.6 \%$ & $-14.4 \%$ \\
\hline Providence, RI & $-5.9 \%$ & $-6.2 \%$ & $-5.5 \%$ & $-7.9 \%$ & $-8.9 \%$ \\
\hline Riverside, CA & $-9.8 \%$ & $-9.8 \%$ & $-9.3 \%$ & $-11.8 \%$ & $-14.4 \%$ \\
\hline Sacramento, CA & $-10.6 \%$ & $-10.8 \%$ & $-10.1 \%$ & $-12.7 \%$ & $-15.8 \%$ \\
\hline San Diego, CA & $-10.7 \%$ & $-11.0 \%$ & $-10.2 \%$ & $-13.1 \%$ & $-19.3 \%$ \\
\hline San Francisco, CA & $-11.3 \%$ & $-11.8 \%$ & $-10.7 \%$ & $-13.4 \%$ & $-20.5 \%$ \\
\hline San Jose, CA & $-12.8 \%$ & $-13.4 \%$ & $-12.2 \%$ & $-15.6 \%$ & $-22.6 \%$ \\
\hline Seattle, WA & $-7.1 \%$ & $-7.2 \%$ & $-6.7 \%$ & $-8.7 \%$ & $-11.8 \%$ \\
\hline St. Louis, MO & $-6.4 \%$ & $-6.7 \%$ & $-6.0 \%$ & $-8.1 \%$ & $-9.1 \%$ \\
\hline Tampa, FL & $-3.9 \%$ & $-4.0 \%$ & $-3.7 \%$ & $-4.6 \%$ & $-5.6 \%$ \\
\hline
\end{tabular}




\section{Virginia Beach, VA}

Washington, D.C.

\begin{tabular}{l|l}
$-9.2 \%$ & $-9.9 \%$ \\
\hline
\end{tabular}

$-13.5 \%-13.2 \%$
$-8.7 \%$

$-12.7 \%$
$-11.2 \%$

$-17.1 \%$
$-15.8 \%$

$-23.5 \%$

The basic simulation refers to the simulated percent change in average house price resulting from eliminating the mortgage interest deduction (MID) with dynamic adjustments and a price elasticity of supply equal to zero, repeated from Table 6, column 5. The Zillow Historic Inflation scenario uses the Zillow Home Value Index for all homes in place of the CoreLogic Home Price Index. The Pure Excise scenario assumes property taxes are purely excise taxes; the Pure Benefit scenario assumes they are pure benefit taxes. The No Risk Premium scenario assumes there is no risk premium to homeownership over a risk-free asset. In each variant all other parameters are equivalent to the basic simulation in column one.

In the second case, local property taxes are viewed as purely excise taxes. This assumption reduces price changes slightly for all cities from the basic case where $k=0.23$. This assumption is seen in the "Pure Excise" series of Fig. 1, and the third column of Table 9. If property taxes are perceived this way, it has the impact of increasing the initial user cost, which leads to smaller percent changes in user cost resulting from a given shift in value when MID policy changes.

In the third case, property taxes are viewed as purely benefit taxes. This eliminates them as a component of user cost, thereby giving shift changes to user cost such as the simulated elimination of the MID a greater impact on a percent-change basis. Estimated price effects in this case are larger in magnitude than in the basic case.

In the fourth case, we remove the risk premium to housing of two percent proposed by Poterba and Sinai (2011). This deepens the impact of eliminating the MID because it reduces the initial user cost. If consumers do not, in fact, price the risk of housing as an asset class into their implicit housing costs, then those implicit costs fall by a greater percentage when the MID is eliminated.

\section{Conclusion}

This paper presents simulated changes to home prices in response to MID reform at the MSA level. We estimate price effects through an extended version of the user cost model of housing that incorporates behavioral change in itemization rates and loan-to-value ratios of borrowers. Our empirical results show that taxpayers are sensitive to the MSR when itemizing, and that borrowers are sensitive to these policies when making an LTV choice.

Our findings show that simulated price changes vary substantially across metropolitan areas, policy changes, and when we consider behavioral change. Differences across metropolitan areas are due in part to variation in income levels and home prices, which affect the MTR households face and the mortgage interest payments they make. In locations with high incomes and high home prices, tax filers more frequently itemize deductions than in locations with low incomes and low home prices, causing the MID to have a greater impact on home prices in those areas.

Considering behavioral change and holding supply elasticity at zero, eliminating the MID results in average home price declines as steep as $13.5 \%$ in Washington, D.C., and as small as 3.5\% in Miami-Fort Lauderdale. Converting the MID to a $15 \%$ refundable credit reduces prices by as much as $1.4 \%$ in San Jose and increases average prices in other metropolitan areas by as much as $12.1 \%$ (Miami-Fort Lauderdale).

When we relax the restriction on supply elasticity and introduce plausible elasticity estimates, local variation in price changes remain, but at substantially lower magnitudes in most cities. On average, these price changes are just $36 \%$ as large as their inelastic counterparts. We view these prices as the 
long-run effect of reforming the MID, once supply has had the opportunity to fully respond to a new level of housing demand.

\section{References}

Albouy and Hanson, 2014 D. Albouy, A. Hanson. Are houses too big or in the wrong place? Tax benefits to housing and inefficiencies in location and consumption. Tax Policy Econ., 28 (2014), pp. 6396, 10.1086/675588

Capozza et al., 1996 D.R. Capozza, R.K. Green, P.H. Hendershott. Taxes, mortgage borrowing, and residential land prices. Economic Effects of Fundamental Tax Reform, Brookings Institution Press, Washington, DC (1996).

Dunsky and Follain, 1997 R.M. Dunsky, J.R. Follain. The demand for mortgage debt and the income tax. J. Hous. Res., 8 (1997), pp. 155-199.

Dunsky and Follain, 2000 R.M. Dunsky, J.R. Follain. Tax-induced portfolio reshuffling: the case of the mortgage interest deduction. Real Estate Econ., 28 (2000), pp. 683-718, 10.1111/15406229.00816

Epple et al., 2015 D. Epple, L. Quintero, H. Sieg. A New Approach to Estimating Hedonic Pricing Functions for Metropolitan Housing Markets. Working Paper (2015).

Federal Reserve Board of Governors, 2015 Federal Reserve Board of Governors. Mortgage Debt Outstanding [WWW Document] (2015) URL http://www.federalreserve.gov/econresdata/releases/mortoutstand/mortoutstand20150331.h tm (accessed 7.24.15)

Feenberg and Coutts, 1993 D. Feenberg, E. Coutts. An introduction to the TAXSIM model. J. Policy Anal. Manage., 12 (1993), pp. 189-194, 10.2307/3325474

Glaeser et al., 2006 E.L. Glaeser, J. Gyourko, R.E. Saks. Urban growth and housing supply. J. Econ. Geogr., 6 (2006), pp. 71-89, 10.1093/jeg/lbi003

Green and Vandell, 1999 R.K. Green, K.D. Vandell. Giving households credit: how changes in the U.S. tax code could promote homeownership. Reg. Sci. Urban Econ., 29 (1999), pp. 419-444, 10.1016/S0166-0462(99)00005-8

Green et al., 2005 R.K. Green, S. Malpezzi, S.K. Mayo. Metropolitan-specific estimates of the price elasticity of supply of housing, and their sources. Am. Econ. Rev., 95 (2005), pp. 334-339.

Hanson, 2012a A. Hanson. Size of home, homeownership, and the mortgage interest deduction. J. Hous. Econ., 21 (2012), pp. 195-210, 10.1016/j.jhe.2012.06.001

Hanson, 2012b A. Hanson. The incidence of the mortgage interest deduction: evidence from the market for home purchase loans. Public Finan. Rev., 40 (2012), pp. 339-359, 10.1177/1091142111422432

Hanson and Martin, 2014 A. Hanson, H. Martin. Housing market distortions and the mortgage interest deduction. Public Finan. Rev., 42 (2014), pp. 582-607, 10.1177/1091142113505679

Hanushek and Quigley, 1980 E.A. Hanushek, J.M. Quigley. What is the price elasticity of housing demand? Rev. Econ. Stat., 62 (1980), pp. 449-454, 10.2307/1927113

Harris, 2013 B.H. Harris. Tax Reform, Transaction Costs, and Metropolitan Housing in the United States. Urban-Brookings Tax Policy Center (2013).

Hendershott and Pryce, 2006 P.H. Hendershott, G. Pryce. The sensitivity of homeowner leverage to the deductibility of home mortgage interest. J. Urban Econ., 60 (2006), pp. 50-68, 10.1016/j.jue.2006.01.003

Hilber and Turner, 2014 C.A.L. Hilber, T.M. Turner. The mortgage interest deduction and its impact on homeownership decisions. Rev. Econ. Stat., 96 (2014), pp. 618-637, 10.1162/REST_a_00427 
Martin, $2015 \mathrm{H}$. Martin. Essays On Housing Tax Policy and Discrimination in the Mortgage Market (Dissertation) Georgia State University, Atlanta (2015).

Mayo, 1981 S.K. Mayo. Theory and estimation in the economics of housing demand. J. Urban Econ., 10 (1981), pp. 95-116, 10.1016/0094-1190(81)90025-5

Poterba, 1984 J.M. Poterba. Tax subsidies to owner-occupied housing: an asset-market approach. Q. J. Econ., 99 (1984), pp. 729-752, 10.2307/1883123

Poterba, 1992 J.M. Poterba. Taxation and housing: old questions, new answers. Am. Econ. Rev., 82 (1992), pp. 237-242.

Poterba and Sinai, 2011 J.M. Poterba, T. Sinai. Revenue costs and incentive effects of the mortgage interest deduction for owner-occupied housing. Natl. Tax J., 64 (2011), pp. 531-564.

Rapaport, 1997 C. Rapaport. Housing demand and community choice: an empirical analysis. J. Urban Econ., 42 (1997), pp. 243-260, 10.1006/juec.1996.2023

Saiz, 2010 A. Saiz. The geographic determinants of housing supply. Q. J. Econ., 125 (2010), pp. $1253-$ 1296, 10.1162/qjec.2010.125.3.1253

Timiraos, 2012 N. Timiraos. President Obama weighs in on mortgage-interest deduction. Wall Street J. (2012).

Voith and Gyourko, 2002 R. Voith, J. Gyourko. Capitalization of federal taxes, the relative price of housing, and urban form: density and sorting effects. Reg. Sci. Urban Econ., 32 (2002), pp. 673690, 10.1016/S0166-0462(02)00011-X

White, $1980 \mathrm{H}$. White. A heteroskedasticity-consistent covariance matrix estimator and a direct test for heteroskedasticity. Econometrica, 48 (1980), pp. 817-838, 10.2307/1912934

${ }^{\star}$ We would like to thank Spencer Banzhaf, Daniel Broxterman, Kurt Schnier, Sally Wallace, Kyle Mangum, Carlianne Patrick, as well as seminar participants at the American Real Estate and Urban Economics Association annual meeting, Federal Reserve Bank of Cleveland, the Federal Housing Finance Agency, the US Census Bureau, Fannie Mae, Baruch College, University of Richmond, and the Tax Economists Forum. All remaining errors are our own.

访 Reserve Bank of Cleveland or of the Board of Governors of the Federal Reserve System.

${ }^{1}$ Capozza et al. (1996) estimate the impact of eliminating both the property tax deduction and the MID to be between 13 and $17 \%$ depending on behavioral change in loan to value ratios. More recently, Harris (2013) estimates the effect of several MID reform options and finds that eliminating the MID would result in an average price decline between 11 and $20 \%$, with varying impacts across metropolitan areas.

${ }^{2}$ An early discussion of this model appears in Poterba (1984).

${ }^{3}$ These deductions are claimed by itemizing on an income tax return. We examine the propensity to itemize and become eligible for these deductions explicitly in the model. Some states allow these deductions on state tax returns, a fact we exploit in the identification of behavioral parameters.

${ }^{4}$ Eq. (1) of Poterba and Sinai (2011) does not include the parameter $k$, but it is introduced further into their paper. We also denote maintenance and depreciation separately to be consistent with earlier forms. 
${ }^{5}$ Simulations in Poterba and Sinai (2011) are conducted for values of $\kappa=0$ and $\kappa=1$. Martin (2015) estimates this parameter to be 0.23 , which is the value we adopt in our simulations. Sensitivity analysis is conducted for the cases $k=0$ and $k=1$ and the results are reported in Table 9.

${ }^{6}$ Previous literature describes the effect of the MID on LTV ratios: see for examples Dunsky and Follain (2000); Hendershott and Pryce (2006), and Poterba and Sinai (2011).

${ }^{7}$ We consider $\pi_{k}$ to measure price appreciation net of physical depreciation in the local market when using historic appreciation rates as a proxy, thus dropping the $\delta$ parameter. Homeowners offset annual depreciation somewhat by spending $m_{k}$ to improve their home. If $m_{k}$ does not restore the home to "like-new" condition, then the quality of the housing stock declines. In the typical model, $\pi$ would reflect the expected gains on the asset in constant quality condition, necessitating the use of $\delta$ to reflect the real-world changes in quality. We posit that when using observed appreciation rates as a proxy for expected price appreciation, any declines in quality are built into resale prices, implying that observed appreciation is the difference between constant quality price appreciation and the value lost to deterioration (i.e. depreciation). This is a departure from Poterba and Sinai (2011), who include a conventional estimate of $\delta$ as well as a historical proxy for $\pi$ in their model. With regard to measuring anticipated price appreciation, we adopt the approach of Martin (2015), which estimates the contribution of historic home appreciation rates to future expectations. We use the factor of 0.4 derived in that work to convert historic appreciation rates to net anticipated appreciation rates in our model.

${ }^{8}$ This follows Albouy and Hanson (2014) who use supply elasticities from Saiz (2010) to examine the deadweight loss in housing consumption and location choice of changing housing tax policy.

${ }^{9}$ Mayo (1981) reviews prior estimates of price elasticities of demand for housing, ranging from 0.2 to 1.3. Hanushek and Quigley (1980) investigate behavior of low-income renters in an experimental context, with estimates ranging from 0.4 to 0.6. Rapaport (1997) emphasizes correcting elasticity estimates for community choice, finding estimates ranging from 0.1 to 1.6 , with higher magnitudes in the preferred specifications. Ongoing work by Epple et al. (2015) estimates a map of price elasticities by income level and household type, ranging from 0.6 to 1.6.

${ }^{10}$ Hilber and Turner (2014) empirically estimate the degree to which the MID is capitalized in different markets due to differences in land use restrictions.

${ }^{11}$ This estimate ignores the tax-filing statuses of single head of household and married filing separately, each of which have MTR schedules that fall between those of married filing jointly and single, due to data limitations. This method guarantees that a given ZIP code's imputed average MTR will be equal to or higher than its actual average MTR, as any tax return of a status other than married filing jointly is grouped in the most aggressive marginal tax schedule. If our estimate overstates (understates) the true MTR, then the simulated price changes would generally be larger (smaller) than the true effects.

${ }^{12}$ Reports of no property tax are not concentrated in one city or city zone, suggesting that zero values are more often failures to report rather than the absence of tax in a particular locale.

${ }^{13}$ Likewise, public reports of the highest property tax rates in the US do not exceed $5 \%$ of home value. (http://www.zillow.com/blog/highest-and-lowest-property-taxes-149303/) 
${ }^{14}$ Counties are split between MSAs only in New England. In our published measures we include a county in an MSA if any part of the county intersects the MSA. Results are not substantially different when we exclude split counties.

${ }^{15}$ Calculations were performed using Internet TAXSIM v9.3 (Feenberg and Coutts, 1993). MID deductibility is verified by entering a taxpayer with a positive tax liability and sufficient mortgage interest to itemize the federal return in each state, and then incrementing the mortgage interest by $\$ 1000$. Decreases in state tax liability are recorded as an indicator that the state allows the MID on its returns.

${ }^{16}$ Ten states have an income tax, but do not allow the MID at the state level.

${ }^{17}$ An additional behavioral change, which we do not discuss here, is the potential for adjustment in interest rates. Hanson (2012b) offers empirical estimates that show contract interest rates are sensitive to the availability of the MID around the $\$ 1$ million debt limit using a regression kink design.

${ }^{18}$ The six states that adopt the MID without adopting the full federal itemization schedule are Arkansas, Hawaii, lowa, Kansas, Kentucky, and Montana. Washington, D.C. is considered a state in our analysis, and is among the 24 states adopting the full federal itemization schedule.

${ }^{19}$ It should be noted that itemization rates may be affected by the instrument directly, since deviations from the federal itemization schedule change the after-tax price of goods that qualify for itemization. Such an effect would bias the IV results.

${ }^{20}$ The second two columns of Table 2 show the first stage results for this IV specification.

${ }^{21}$ Throughout the policy simulations we assume that states do not change their tax laws. In a state that explicitly adopts the MID but does not allow all federal deductions, we assume it will keep this allowance regardless of the federal change to MID availability. Hence, UseFed $d_{j}=0,\left(1-\right.$ UseFe $\left._{j}\right)=1$ and the indicators given suggest the state-level deduction remains intact. In a state which allows the MID by adopting the standard federal schedule of itemizations, UseFed $d_{j}=1,\left(1-\right.$ UseFed $\left._{j}\right)=0$, indicating that the deduction is removed due to existing laws harmonizing state and federal itemization schedules. States without the MID continue not to offer it. In metro areas that cross state lines, UseFed $_{j}$ is an average weighted by number of tax filers in each state living in a metro area, and falls between zero and one, reflecting the metro area's average propensity to use the federal itemization schedule. In each case, the indicators result in the appropriate total deduction being conferred to each metro area consistent with no changes to state law.

${ }^{22}$ Because the average marginal tax bracket for most of the markets is lower than $28 \%$, the simulation is unable to pick up the effects of such a high cap.

${ }^{23}$ Saiz (2010) produces supply elasticities for all cities in our study except Sacramento. 